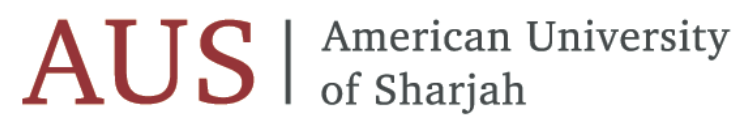

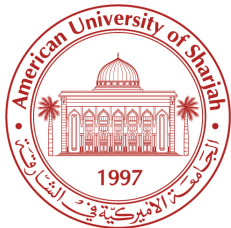

SCHOOL OF BUSINESS AND MANAGEMENT WORKING PAPER SERIES

SBMWPS: $12-11 / 2013$

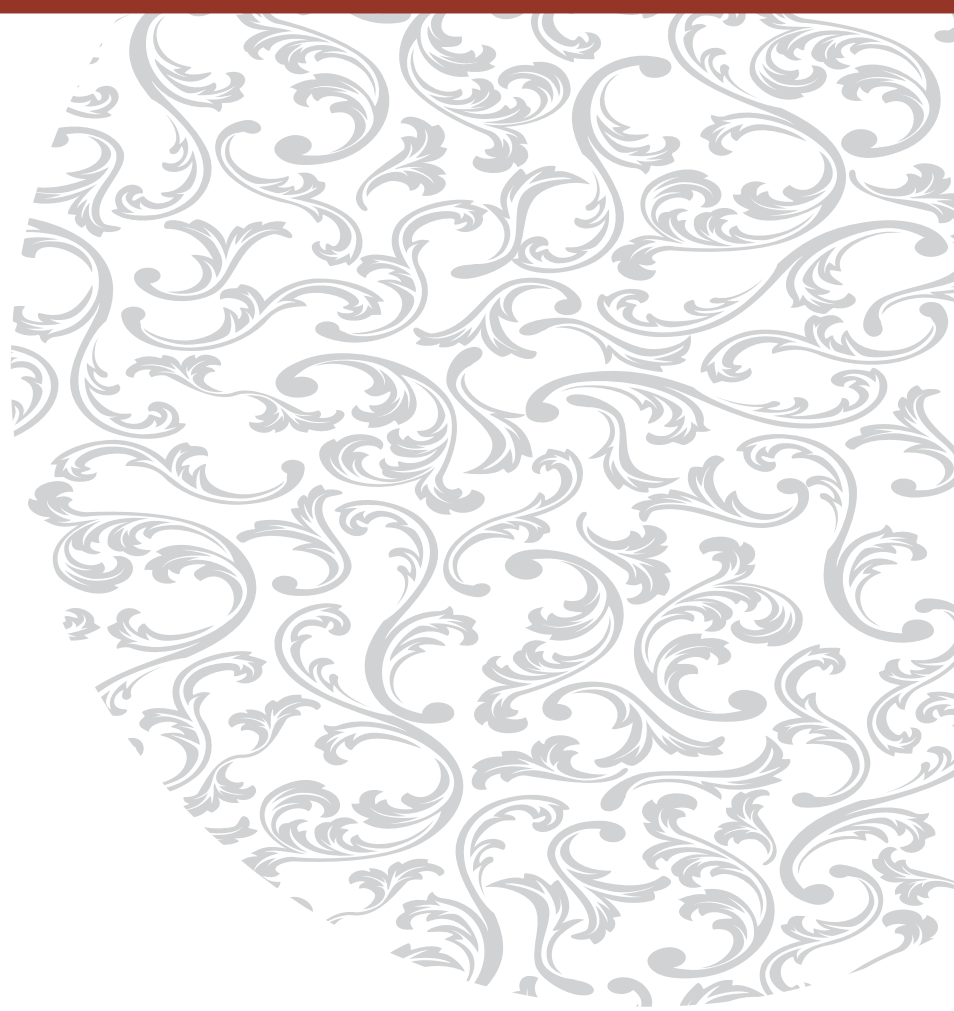

International Diversification and

Corporate Social Responsibility

Najah Attig

Narjess Boubakri

Sadok El Ghoul

Omrane Guedham 


\title{
International Diversification and Corporate Social Responsibility
}

\author{
Najah Attig \\ Saint Mary's University (Halifax)

\section{Narjess Boubakri} \\ American University of Sharjah
}

\section{Sadok El Ghoul}

University of Alberta

\section{Omrane Guedham}

University of South Carolina

The views expressed in papers published in our series are those of the author(s) and do not necessarily represent those of any department at SBM, the SBM itself, the American University of Sharjah (AUS) and/or any of their affiliates. Additionally, all papers in the series are made available on an "as is" basis without warranties of any kind. We, that is, the relevant department at SBM, SBM, AUS and/or any of the affiliates, hereby expressly disclaim any warranties of any kind, whether expressed or implied, including without limitation, the warranties of noninfringement, merchantability, and fitness for a particular purpose. Furthermore, we offer no warranties, expressed or implied, regarding the accuracy, sufficiency or suitability of the material found in the published papers. The users have the sole responsibility for inspecting and testing all content to their satisfaction before using them. 


\section{International Diversification and Corporate Social Responsibility*}

Najah Attig

Saint Mary’s University, Halifax, NS B3H 3C3, Canada

Narjess Boubakri

American University of Sharjah, Sharjah, UAE

Sadok El Ghoul

University of Alberta, Edmonton, AB T6C 4G9, Canada

Omrane Guedham

University of South Carolina, Columbia, SC 29208, USA 


\begin{abstract}
Using a large sample of 3,040 U.S. firms and 16,606 firm-year observations over the 1991-2010 period, we find strong evidence that firm internationalization is positively related to the firm's corporate social responsibility (CSR) rating. This finding persists when we use alternative estimation methods, samples, and proxies for internationalization and when we address endogeneity concerns. Next, we find that firm characteristics such as size, profitability, growth opportunities, R\&D, and advertising expenses condition the link between internationalization and CSR. We finally provide novel evidence that firms with extensive foreign subsidiaries in countries with well-functioning political and legal institutions have better CSR ratings.
\end{abstract}

Keywords: Corporate international diversification; corporate social performance; institutional environments

* We appreciate the generous financial support from Canada's Social Sciences and Humanities Research Council. 
“Globalization has increased calls for corporations to use firms' resources to help alleviate a wide variety of social problems” (Hillman \& Keim, 2001: 125)

\section{INTRODUCTION}

Motivated by the growing attention paid to corporate social responsibility (CSR) by researchers and society at large, ${ }^{1}$ we investigate the extent to which CSR is influenced by corporate international diversification, and whether the quality of host countries' governance institutions shape this relationship. Firm internationalization refers to a strategy "through which a firm expands the sales of its goods or services across the borders of global regions and countries into different geographic locations or markets” (Hitt, Ireland, \& Hoskisson, 2007: 251). On a prima facie basis, firm internationalization can be viewed as a strategy to increase and maintain a firm's competitive advantage (e.g., Nachum \& Zaheer, 2005) through enhanced economies of scale and scope (Kogut, 1985), growth opportunities (Porter, 1990), and diversification benefits (e.g., Geringer, Beamish, \& DaCosta, 1989), as well as access to new resources, production capabilities, and knowledge (Hitt, Hoskisson, \& Kim, 1997). To the extent these factors increase a firm's competitive advantage, internationalization should lead to performance improvements and value creation. An alternative view holds that internationalization increases uncertainty and complexity. For instance, firms expanding internationally face not only the liability of foreignness (Zaheer, 1995), psychic distance (Johanson \& Vahlne, 1977), and the hostility of an international environment (Zahra \& Garvis,

\footnotetext{
${ }^{1}$ For instance, in an international survey of directors and managers from publicly and privately held firms, $85 \%$ of U.S. respondents agreed with the statement, "Corporations need to create shareholder value in a way that aligns with society's interests, even if that means sacrificing shareholder value.” Similarly, a survey by KPMG (2011) shows that the percentage of Fortune Global 250 firms that issues stand-alone CSR reports has increased from 52\% in 2005 to $80 \%$ in 2008 and 95\% in 2011. The Social Investing Forum reports that in the U.S., as of 2010, \$3.07 of \$25.1 trillion is managed under the guidelines for Socially Responsible Investment.
} 
2000), but also pressure from new and more diverse stakeholders (e.g. customers, employees, suppliers, competitors, and regulators). ${ }^{2}$ These factors cast doubt on the ability of international diversification to create value and improve performance.

Existing studies on the value impact of internationalization focus largely on accountingand finance-based measures of financial performance. In contrast, the literature has had little to say about the impact of international diversification on a firm's CSR performance. This is striking given that multinational corporations have regularly come under attack for being socially irresponsible, as demonstrated, for instance, by the protests during the WTO meetings as well as high-profile media reports (e.g., revelations in the New York Times about Nike’s abusive labour practices in Indonesia). This paper contributes to filling this void in the literature by examining the impact of corporate international diversification on CSR.

The few prior studies that link firm internationalization and firms’ social behavior provide mixed evidence: Brammer, Pavelin, \& Porter (2006, 2009) and Kang (2013) document a positive relationship between international diversification and CSR, for a sample of U.K. and U.S. firms, respectively. ${ }^{3}$ Using a panel of 511 large U.S. firms over the 1993-2006 period, Kang (2013) confirms prior evidence in Strike, Gao, \& Bansal (2006) for a sample of 222 publicly traded U.S. firms over the 1993-2003 period. Simerly (1997) and Simerly \& Li (2000) however do not find a significant link between CSR and firm internationalization for their sample of 350 U.S. firms over the 1991-1996 period. Our study adds to this evidence and contributes to this line

\footnotetext{
${ }^{2}$ Zaheer (1995: 342) defines liability of foreignness as "the costs of doing business abroad that result in a competitive disadvantage”. Psychic distance refers to uncertainty associated with factors such as "differences in language, culture, political systems, level of education, or level of industrial development" that adversely affect the flow of information between a firm and the market (Johanson \& Vahlne, 1977: 24).

${ }^{3}$ Brammer, Pavelin, \& Porter (2006, 2009) focus specifically on the CSR dimensions of community and environment (corporate charitable giving).
} 
of research by using the largest U.S. and most diverse multinational samples to date: 3,040 unique U.S. firms representing 16,606 firm-year observations over the 1991-2010 period, and a sample of non-U.S. firms (6,998 firm-year observations) from 42 countries over the 2002-2010 period.

By focusing on firm CSR rating as a dependent variable, our study contributes to the sparse CSR literature that characterizes the determinants of firms' corporate social performance. ${ }^{4}$ We adopt the strategic view of CSR (Orlitzky, Siegel, \& Waldman, 2011), which holds that voluntary CSR actions positively affect primary stakeholders' interests and enhance the firm's competitiveness and reputation. ${ }^{5}$ Accordingly, we argue that a firm's degree of international diversification is likely to increase its socially responsible activities or investment (and thus CSR rating). This is likely the case because firms that diversify internationally tend to face increased demand for socially responsible corporate behaviour from new and more diverse stakeholders.

To validate this contention we conduct four sets of tests: First, we examine the association between internationalization and a firm's CSR rating (drawn from MSCI ESG Research). We find that internationalization is significantly positively related to a firm's CSR rating, confirming the earlier evidence of Brammer, Pavelin, \& Porter (2006, 2009) and Kang (2013). In additional tests we check the robustness of our results to alternative measures of internationalization, different subsample periods, and different estimation methods. The results continue to hold. Moreover, our results are robust to using Thomson Reuters ASSET4 as an

\footnotetext{
${ }^{4}$ For instance, only 18 of the 127 reviewed studies from 1972 to 2002 by Margolis \& Walsh (2003) treated CSR as the dependent variable (Campbell, 2007). Margolis \& Walsh (2003: 297) stress the need for understanding "the conditions under which a corporation's efforts benefit society" before understanding the "link between a firm's social and financial performance."

${ }^{5}$ This definition of CSR reflects firm actions that "appear to further some social good, beyond the interests of the firm and that which is required by law” (McWilliams \& Siegel, 2001: 117).
} 
alternative source of CSR ratings for U.S. firms. We further provide the first multinational evidence on the positive relation between international diversification and CSR using a large panel of non-U.S. firms from 42 different countries. To address potential endogeneity resulting from the direction of causality between internationalization and its outcomes, we use instrumental variables estimation, propensity score matching, and Heckman sample selection. While one cannot fully eliminate endogeneity concerns, they do not appear to drive the association we document between internationalization and CSR.

Second, we extend earlier research and delve deeper into that association by separately investigating the effect of internationalization on CSR strengths and concerns, and find that a firm’s internationalization loads significantly (positively) only on CSR strengths. In a related test, we examine the impact of internationalization on the individual components of CSR. The results suggest that only the CSR dimensions related to employee rights and product characteristics are not influenced by a firm’s internationalization. In a nutshell, the CSR activities that seem to matter most for the social behavior of multinational firms are the discretionary activities.

Third, in a major departure from prior studies we investigate whether varying country institutions and laws across the locations of the firm's subsidiaries shape multinationals' CSR activities differently. We provide novel evidence that multinationals with extensive subsidiaries in countries with strong political and legal institutions display higher CSR ratings. This finding goes beyond the mere evidence in earlier studies that diversification is positively related to CSR, and underscores the conditioning role of the institutional environments in which the firm’s subsidiaries operate. 
Finally, in an additional test we examine whether firm characteristics influence the internationalization-CSR relationship. We extend the work of Servaes and Tamayo (2013), who find that a firm's information environment conditions the internationalization-CSR relation, to examine a comprehensive set of firm characteristics. We find that only multinationals with more political visibility (e.g., larger and older) and those with higher growth opportunities (e.g., high market-to-book value, high R\&D expenses, high advertising expenses) and more abundant resources increase their CSR investments. This result lends some support to the resource-based theory that stresses core resources and capabilities as drivers of an international firm’s competitive advantage, and highlights CSR investment as a channel to achieve the benefits of internationalization.

In summary, the four sets of tests in this study provide new evidence on what drives a firm’s social behavior, and emphasize CSR as an increasingly important strategy for achieving and maintaining competitive advantages from internationalization.

The rest of the article proceeds as follows. In the next section, we briefly review related literature and elaborate on our main hypotheses. In Section 3 we describe our data and summarize our research design. We present results in Section 4. Finally, we conclude in Section 5.

\section{LITERATURE BACKGROUND AND HYPOTHESIS}

Our premise in this paper, that internationalization leads to more corporate socially responsible behaviour (and thus higher CSR rating), is grounded in the following arguments. First, entering new markets increases the number of a firm’s stakeholders (Sharfman, Shaft, \& Tihanyi, 2004). In line with the good management hypothesis of CSR (Waddock \& Graves, 
1997) and the argument in Brammer, Pavelin, \& Porter (2009: 579) that "the continued involvement of stakeholders with a business is to some significant degree contingent upon the stakeholders' belief that the organization is a socially responsible company”, multinational firms are likely to invest in CSR to strengthen their reputation as socially responsible actors and improve their image with new and existing stakeholders. Second, entering new markets increases the diversity of a firm's stakeholders in terms of cultural, political, institutional, and economic characteristics. Firms diversifying internationally can respond to the increased diversity of expectations by adopting high CSR standards (Sharfman, Shaft \& Tihanyi., 2004; Kostova \& Zaheer, 1999; Brammer Brammer, Pavelin, \& Porter, 2009 and references therein). Third, entering new markets increases litigation risk if firms violate societal and/or regulatory requirements. In the spirit of Feldman, Soyka, \& Ameer (1997), who show that firms that adopt an environmentally proactive posture significantly reduce their perceived risk, we posit that multinational firms can reduce their perceived risk ${ }^{6}$ and the uncertainty associated with their multinationality by increasing their CSR investment. Fourth, CSR can alleviate communication problems (Zahra, Ireland, \& Hitt, 2000) and the adverse effects of psychic distance. Fifth, internationalization increases a firm's disclosure informativeness (Riahi-Belkaoui, 2001), which can lead to better social performance because high CSR firms are associated with better information quality (Dhaliwal, Li, Tsang, \& Yang, 2011). This is likely the case because high CSR firms are associated with increased analyst coverage and in turn investor and media attention (Hong \& Kacperczyk, 2009; El Ghoul, Guedhami, Kwok, \& Mishra, 2011). Sixth,

\footnotetext{
${ }^{6}$ Consistent with lower perceived risk, El Ghoul, Guedhami, Kwok, \& Mishra (2011) and Attig, El Ghoul, Guedhami, \& Suh (2013), respectively, find that high CSR firms enjoy lower financing costs and improved credit ratings. CSR can also reduce the risk of costly sanctions by stakeholders. For instance, in line with the finding in Maksimovic \& Titman (1991) that firm stakeholders are reluctant to do business with a highly levered firm, Bae Kang, \& Wang (2011) show high CSR firms - evident in their ability to offer fair employee treatment—maintain lower leverage.
} 
based on the argument that market (resource) commitment can help to create and maintain a firm's competitive advantage (Andersen, 1993), multinational firms can signal their resource commitment to a new foreign market by increasing their CSR activities. ${ }^{7}$ In addition, Kang (2013) posits that managers of diversified firms become more responsive to stakeholder demands and social issues because diversification aggravates managerial risk aversion and lowers managerial employment risk. Accordingly, our first and main hypothesis is as follows:

\section{$H_{1}$ : Internationalization is positively related to higher CSR ratings}

Next, we examine the extent to which internationalization influences differently CSR concerns and strengths. This test is useful because aggregating CSR strengths and concerns may overlook cross-sectional variation in CSR behaviour (Chatterji, Levine, \& Toffel, 2009). ${ }^{8}$ Strike Gao, \& Bansal (2006), for instance, provide evidence that multinational firms are likely to be operating both responsibly and irresponsibly, and argue that CSR should be decomposed into its negative and positive aspects (concerns and strengths, respectively). Given the strategic perspective of internationalization, we expect a positive link between CSR strengths and internationalization. Indeed, using the argument of Hart (1995), Attig (2011) further stresses that CSR strengths are proactive in nature and more costly to implement, but more beneficial than avoiding CSR concerns. This is likely the case because CSR concerns tend to relate to industry standards or minimum social performance levels expected by the public (e.g., Figge, Han, Schaltegger, \& Wagner, 2002). Along this line of thinking, Servaes and Tamayo (2013: 10) argue that CSR strengths "should matter more when capturing the CSR efforts made by firms

\footnotetext{
${ }^{7}$ To some extent, this is related to the view of Hsu \& Pereira (2008: 190) that "the value of internationalization comes from an increase in the economic rent that accrues to those firm-specific resources."

${ }^{8}$ As Kim, Park, \& Wier (2012: 784) state, "a firm with five strengths and five concerns is surely different from a firm with one strength and one concern”.
} 
than concerns". The authors argue that CSR concerns are likely to reflect the outcome of other decisions rather than specific efforts of the firm's social behaviour. Supportive evidence is provided by Kim, Park, \& Wier (2012) who show that CSR strengths (concerns) are associated with more conservative (aggressive) financial reporting. Building on arguments above, our second hypothesis is as follows:

\section{$\mathrm{H}_{2}$ : Internationalization is positively (negatively) related to CSR strengths (concerns)}

As we previously argued, the multidimensionality of internationalization may entail different social activities for different stakeholders. In addition, CSR is a multidimensional construct (Carroll, 1979). As such, using an aggregate CSR score might mask the relevance of its sub-dimensions in different contexts (Griffin \& Mahon, 1997; Attig, 2011; Benabou \& Tirole, 2010; Galema, Plantinga, \& Scholtens, 2008). Hillman \& Keim (2001) distinguish two main groups of CSR components: those that are directly related to a firm's primary stakeholders (e.g., Employee Relations, Diversity, Product Characteristics, Community, and Environment) and those that reflect participation in social issues and are not directly related to a firm's primary stakeholders (e.g., Human Rights). Given the importance of investing in relationships with stakeholders as a strategy for increasing competitive advantage, one might argue that internationalization will have a greater effect on the CSR dimensions related to the firm's primary stakeholders. However, some CSR dimensions related to those stakeholders are likely to be socially required, as opposed to socially desired (Attig, El Ghoul, Guedhami, \& Cleary, 2013). For instance, employee relations and product characteristics are, to a significant degree, influenced by legal and regulatory requirements and hence international diversification may have little or no impact on these aspects of social performance (Brammer, Pavelin, \& Porter, 2006). Building on this stream of thinking, we predict that internationalization is more likely to be 
related to discretionary CSR dimensions that are less regulated (e.g., Diversity, Community, Environment, and Human Rights). Our third hypothesis is then:

$H_{3}$ : Internationalization is positively related CSR dimensions that relate to the interests of the firm's primary stakeholders

To shed further light on the relevance of internationalization in shaping the CSR of multinational firms we investigate the extent to which the host-country institutions and laws affect corporate social behaviour of multinational firms. Murtha \& Lenway (1994) suggest that national institutional factors exert great influence on a firm’s non-market behavior and strategies. While empirical research offering convincing support for the impact of institutional and legal factors on corporate outcomes (e.g., La Porta, Lopez-de-Silanes, Shleifer, \& Vishny, 1998) is abundant, Ioannou \& Serafeim’s (2012) work is of more relevance to this study. The authors find that country (e.g., political and legal) institutions are important determinants of social and environmental performance. ${ }^{9}$ Building on this stream of research, we posit that multinational firms adjust their CSR activities to successfully manage the diversity of host countries’ institutional environments. To test this prediction, we examine whether variation in political risk, government stability, investment profile, control of corruption, law-and-order rating, democratic accountability, and quality of bureaucracy that apply to a firm's foreign subsidiaries affects the firm’s CSR rating. Accordingly, our fourth hypothesis is as follows:

$\mathrm{H}_{4}$ : The institutional and political environments of the host-countries condition the link between firm internationalization and its CSR ratings

\footnotetext{
${ }^{9}$ Dyreng, Hanlon, \& Maydew (2012) find that firms with extensive foreign subsidiaries in countries with a low rule of law engage in more earnings management than other firms.
} 


\section{DATA AND RESEARCH DESIGN}

\subsection{Sample Selection}

Our sample is drawn from two databases: Compustat and Compustat Segments, which we use to obtain financial information and to construct our internationalization variables, respectively, and MSCI ESG STATS, which we use to obtain CSR scores. MSCI ESG STATS, together with its predecessor KLD Stats, is widely used in CSR studies (e.g., Hillman and Keim, 2001; Chatterji, Levine, \& Toffel, 2009; Bae, Kang, \& Wang, 2011; Servaes and Tamayo, 2013)

To construct our sample, we begin with all firms from Compustat over the 1991-2010 period with non-missing financial information. We eliminate financial firms (SIC codes between 6000 and 6999). We also eliminate firm-years for which the sum of geographic segment sales is not within one percent of total reported firm sales. Next, we match our Compustat sample with MSCI ESG STATS, which evaluates each firm along 13 CSR dimensions using surveys, financial statement information, media reports, government documents, regulatory filings, proxy statements, and peer-reviewed legal journals. These 13 CSR dimensions are grouped into two major categories: qualitative issue areas and controversial business issues. Qualitative issue areas are Community, Corporate Governance, Diversity, Employee Relations, Environment, Human Rights, and Product Characteristics. For each area, we calculate a score equal to the number of strengths minus the number of concerns. We then sum the scores to obtain an overall CSR score (CSR_S). This approach is commonly used in the CSR literature (e.g., Kim, Park, \& Wier, 2012; El Ghoul, Guedhami, Kwok, \& Mishra, 2011; Goss and Roberts, 2011). After these screenings, our final sample contains 3,040 U.S. firms and 16,606 firm-year observations over the 19912010 period. Appendix A provides details on the construction of the CSR variables. 
Table 1 presents a breakdown of our sample by industry (using the Fama-French 48industry classification) and year. The sample distribution by industry indicates that a relatively sizeable percentage of our sample (11.22\%) belongs to Business Services. As can be seen from the table, the number of firms per year is fairly evenly distributed in the 300 range over the 19912000 period, increasing to the 500 range in 2001 and 2002 before rising dramatically to between 1,300 and 1,800 firms per year over the 2003-2010 period. The increase in the number of firms per year is largely due to increased sample coverage. In particular, firm coverage in MSCI ESG STATS has increased steadily over time. In 1991-2000, coverage consisted of the S\&P 500 and the Domini Social Index. The Russell 1000 Index was added in 2001, the Large Cap Social Index in 2002, and both the Russell 2000 Index and the Broad Market Social Index in 2003.

\section{Table 1 goes here}

Panel A of Table 2 reports summary statistics for our aggregate CSR measure by year. This table shows that the mean CSR score declines to become negative in 2004, and remains negative until the end of our sample. The sharp decline corresponds to the number of observations more than doubling in 2004 due to the inclusion of a broader sample of firms in the database. The median also becomes negative in 2005 and remains so until 2010. Panel B of Table 2 shows that in the 2004-2010 period the average number of strengths (CSR_STR) declined relative to the earlier period, while the average number of concerns (CSR_CON) increased only slightly. As a result of these two trends, the overall mean CSR score declined during this period. 
Table 2 goes here

\subsection{Regression Models and Variables}

To analyze the impact of firm internationalization on CSR, we run variations of the following model:

CSR_S $=\alpha+\beta_{1} \cdot$ INTERNATIONALIZATION $+\beta_{2} \cdot Z+$ FIXED EFFECTS $+\varepsilon$,

where CSR_S is the firm's CSR score. INTERNATIONALIZATION is one of the proxies for the degree of firm internationalization defined below. FIXED EFFECTS comprises time and industry fixed effects. $Z$ is a vector of control variables. Following prior related research (e.g., Strike, Gao, \& Bansal, 2006), we control for the following variables: size, measured as the logarithm of total sales (SIZE); the logarithm of firm age, defined as the number of months since the firm first appeared in the CRSP database ( $\left.L O G \_A G E\right)$; return on assets (ROA); the market value of assets, which is equal to market capitalization plus total assets minus book value of equity $(M T B)$; leverage ratio, defined as total debt divided by total assets ( $L E V)$; the ratio of research and development expenses to total sales $(R \& D / S)$; and the ratio of advertising expenses to total sales $(A D V / S)$. More detailed variable definitions are provided in Appendix B.

Panel A of Table 3 provides summary statistics for the variables used in our regression analysis. Panel B presents a correlation matrix between our key variables. Of relevance to our study is the positive and significant (at the 1\% level) correlation between CSR (CSR_S) and internationalization $(F S / S)$. Generally, the pairwise correlation coefficients among the control variables are low, suggesting that multicollinearity is not of concern in our analysis. 


\section{Table 3 goes here}

\section{EMPIRICAL EVIDENCE}

\subsection{Effects of Internationalization on CSR}

4.1.1 Main evidence. Table 4 reports the results of estimating Equation (1) using ordinary least squares (OLS), with standard errors corrected for heteroskedasticity and clustering by firm to account for the lack of independence of observations within a given firm over time. In Model 1 we regress CSR score (CSR_S) on the ratio of foreign sales to total sales $(F S / S)$ —our first proxy for firm internationalization — and a set of controls. We find support for our conjecture on the internationalization-CSR link: the estimated coefficient on FS/S is positive and statistically significant (at the 1 percent level), indicating that an increase in foreign operations leads to a higher CSR rating. This confirms previous results in Strike, Gao, \& Bansal (2006) and Kang (2013). Taken together, this evidence suggests that CSR activities can help firms mitigate market imperfections and asymmetric information problems as well as manage complexities stemming from new and diverse stakeholders.

To comprehensively examine the impact of internationalization on CSR, we replace FS/S with several alternative measures of firm internationalization. In particular, we use the ratio of foreign assets to total assets (FA/A) in Model 2, the Herfindahl Index measures of geographical diversification in firm sales (HERFINDAHL_S) and assets (HERFINDAHL_A) in Models 3 and 4, and the entropy index measures of corporate diversification in firm sales (ENTROPY_S) and assets (ENTROPY_A) in Models 5 and 6, respectively. Reinforcing our finding from Model 1, all 
the proxies for firm internationalization are consistently positively and significantly related to CSR_S, providing further support to the prediction of our first hypothesis $\left(H_{1}\right)$ that firm internationalization increases CSR engagement.

Turning to the control variables, we document several significant relations. The estimated coefficients on profitability $(R O A)$, market-to-book $(M T B)$, R\&D intensity $(R D / S)$, advertising expenses (ADV/S), size (SIZE), and age (LOG_AGE) are generally positive and statistically significant, suggesting that they increase CSR ratings. Firm leverage (LEV), however, loads significantly negatively on CSR_S, suggesting that an increase in leverage leads to a lower CSR rating. The negative effect of $L E V$ is in line with the argument of Roberts (1992) that an increase in leverage is associated with more preferential attention to creditors at the expense of other stakeholders.

Table 4 goes here

In Table 5, we examine the stability of the internationalization-CSR relation over time. To do so we re-estimate Equation (1) over four consecutive five-year subsample periods: 19911995, 1996-2000, 2001-2005, and 2006-2010. During the 1991-1995 period, the coefficient on $F S / S$ is positive but statistically insignificant at conventional levels. In contrast, the coefficient on FS/S in the three other subsample periods loads significantly positively. While it is possible that the internationalization-CSR link can be time-dependent, the data in Table 5 provide support for our prediction on the societal implications of international diversification. 


\section{Table 5 goes here}

4.1.2 Sensitivity tests. In Tables 6-8 we subject our main finding to several sensitivity tests to verify the robustness of our evidence on the link between internationalization and CSR activities.

Endogeneity. Although our results on the internationalization-CSR relationship are insightful, they should be interpreted with caution as we cannot rule out alternative explanations. For instance, CSR as an organizational resource may help firms expand internationally. To mitigate concerns of endogeneity we use three approaches and report our findings in Table 6 . First, in Panel A we implement an instrumental variable (IV) estimation procedure where we use three instruments to extract the exogenous component of $F S / S$ : (1) $M I D$, a dummy variable set to 1 if the firm reports minority interest on its balance sheet, (2) PNFOR, the fraction of firms with positive FS/S in the firm's industry in a given year, and (3) STATE_FS/S, the ratio of foreign sales of all firms headquartered in the state to foreign sales of all sample firms in a given year. We regress FS/S on the three instruments and all the controls in Equation (1). Regression results of this first-step regression are reported in Model 1. We then retain the predicted value of FS/S and use it instead of FS/S in the regressions examining the effect of internationalization on CSR. We use 2SLS, LIML, and GMM estimations, respectively, in Models 2, 3, and 4. The results reported in Model 1 suggest that the three instrumental variables are significantly positively related to our internationalization proxy $(F S / S)$. Importantly, the second-stage regressions results in Models 2 through 4 consistently show that the impact of the predicted value of FS/S is positive and statistically significant at the 5 percent level, reinforcing our OLS findings in Table 4. 
Second, in Panel B of Table 6 we employ the propensity score matching (PSM) procedure proposed by Rosenbaum \& Rubin (1983). To implement PSM we start by constructing a multinational dummy variable that takes the value of 1 if $F S / S>0$, and 0 otherwise. We then estimate a probit model where we regress the multinational dummy on all controls, and we use the scores to match (using different approaches) each observation with multinational dummy $=1$ to an observation with multinational dummy $=0$. We use the resulting sample in our regression. Interestingly, our key variable (multinational dummy) loads significantly positively on CSR independent of the matching method used, lending further support to our main finding that internationalization leads to a higher CSR rating. As such, CSR seems to play a non-negligible strategic role in reducing market imperfections and managing the complexity and uncertainty arising from entering new international markets.

Third, in Panel C of Table 6 we employ the Heckman self-selection (two-step) model. In the first step, we use a probit model to regress a dummy variable that equals 1 if $F S / S>0$, and 0 otherwise, on all control variables from our main specification (Column 1 in Table 4) and the instrumental variables used in Panel A of Table 6 (MID, PNFOR, and STATE_FS/S). In the second stage, the firm's CSR score $\left(C S R \_S\right)$ is the dependent variable, and we include the selfselection parameter (inverse Mills' ratio) estimated from the first stage. The results of the twostep estimation model continue to suggest that internationalization is positively associated with a higher CSR rating.

\section{Table 6 goes here}


Alternative Estimation Methods. We next test the robustness of our main results to the use of two alternative estimation methods. First, we exploit the panel nature of our data by estimating fixed and random effects models. In the results reported in Models 1 and 2 of Table 7, we continue to find that internationalization is significantly positively related to a firm's CSR rating. These regressions help dispel concerns that omitted variables and unobserved heterogeneity are spuriously behind our main finding. Second, following Petersen (2009) and Gow et al. (2010) we use different estimation methods to control for cross-sectional and serial dependence, namely, Newey-West in Model 3, Fama-McBeth in Model 4, Prais-Winsten in Model 5, and two-way clustering by firm and year in Model 6 of Table 7. Importantly, the estimated coefficient on FS/S loads significantly positively on CSR in all these regressions, indicating that our main evidence on the positive association between CSR and internationalization is unaffected by the use of different estimation methods.

\section{Table 7 goes here}

Alternative Samples. To shed further light on the validity of our findings, we use Thomson Reuters ASSET4 as an alternative source of CSR ratings to extend our sample to nonU.S. firms from 42 countries over the 2002-2010 period. The results are reported in Table 8. When we run our regression model in Equation (1) using the full sample (i.e., both U.S. and nonU.S. firms), as shown in Model 1, the estimated coefficient on FS/S bears significantly positively on the alternative measure of CSR activity. Interestingly, this result remains qualitatively unchanged when we run our regression model separately for the U.S. and non-U.S. firm 
subsamples. The results in Table 8 therefore reinforce our main evidence in Table 4 that internationalization influences firms’ CSR activities.

\section{Table 8 goes here}

\subsection{Effects of Internationalization on the Components of CSR}

In order to validate our second and third hypotheses we extend our analysis to examine the link between internationalization and different dimensions of the overall social performance score. We begin in Models 1 and 2 by testing the effect of internationalization on CSR strengths (CSR_STR) and concerns (CSR_CON), respectively. In line with our second hypothesis $\left(\mathrm{H}_{2}\right)$, we find that the estimated coefficient on FS/S loads significantly positively on CSR strengths (CSR_STR), while it does not have any significant effect on CSR concerns (CSR_CON). This evidence suggests that internationalization increases CSR strengths, but has no effect on CSR concerns. This result provides only partial support for Strike, Gao, \& Bansal (2006), who find a positive relationship between firm internationalization and both CSR and corporate social irresponsibility. One potential explanation for the difference in results is that as firms expand the international geographical scope of their operations, they invest proactively in CSR by enhancing CSR strengths, as doing so enhances the firm's image as a socially responsible firm and in turn its competitive advantage. In contrast, firms are unlikely to devote effort to CSR concerns (Servaes \& Tamayo, 2013) as avoiding CSR concerns is usually achieved by complying with the minimum industry standards. 


\section{Table 9 goes here}

Next, we examine the effects of internationalization on the individual dimensions of CSR. Specifically, we look at the following six attributes included in the CSR rating: Community (CSR_COM_S) in Model 3, Diversity (CSR_DIV_S) in Model 4, Employee Relations (CSR_EMP_S) in Model 5, Environment (CSR_ENV_S) in Model 6, Human Rights (CSR_HUM_S) in Model 7, and Product Characteristics (CSR_PRO_S) in Model 8. The results suggest that the effects of internationalization vary across the six CSR dimensions. First, internationalization loads significantly negatively on the dimension Human Rights (CSR_HUM_S). Second, internationalization loads significantly positively only on the CSR dimensions related to the firm's primary stakeholders and less likely to be determined by compliance (i.e., Community (CSR_COM_S), Diversity (CSR_DIV_S), and Environment (CSR_ENV_S)), as they appear to be socially desired. In contrast, firm internationalization does not seem to have a significant effect on the dimensions Employee Relations (CSR_EMP_S) and Product Characteristics (CSR_PRO_S). These findings provide some support to the evidence in Brammer, Pavelin, \& Porter (2006) that, for a sample of U.K. firms in 2002, geographical diversification has a positive relationship with the CSR dimensions Community and Environment but no relationship with the Employee Relations dimension.

Taken together, the findings in Table 9 are to a large degree consistent with our expectations of our third hypothesis $\left(H_{3}\right)$. As such they lend support to the finding of Hillman \& Keim (2001) that the relevant CSR dimensions are those directly related to firms’ primary stakeholders (Employee Relations, Diversity, Product Characteristics, Community, and Environment). These dimensions appear to help multinational firms manage the complexities of 
internationalization that arise from greater pressures from a larger and more diverse group of stakeholders. In contrast, results from the regression of the dimension that reflects a firm's participation in social issues (i.e., Human Rights) suggest that firms entering new markets do not invest in social issues, perhaps because multinational firms do not recognize competitive advantage benefits from doing so. Similarly, internationalization does not appear to bear on the product and employee CSR dimensions, which are largely determined by legal, regulatory, or societal requirements and have a more direct impact on the financial performance of multinational firms.

\subsection{Impact of the Institutional Environment on CSR Ratings}

To validate our fourth hypothesis $\left(H_{4}\right)$ we analyze the extent to which a U.S. multinational firm's CSR rating is affected by the institutional environment of the location of its foreign subsidiaries. To do so we analyze the subsample of U.S. firms that disclose subsidiaries in Exhibit 21 of Form 10-K and control for a set of institutional variables obtained from the International Country Risk Guide. For each institutional variable, we follow Dyreng, Hanlon, \& Maydew (2012) and compute the weighted average institutional rating of countries in which the firm discloses subsidiaries. ${ }^{10}$ The results are reported in Table 10.

In Model 1 we examine whether variation in the local political risk rating that applies to foreign subsidiaries affects the U.S. parent. The estimated coefficient on POLIT_RISK is positive and significant at the 1 percent level, suggesting that, all else being equal, geographical diversification in countries with more political stability is associated with higher CSR ratings. The estimated coefficient on the weighted average government stability rating of countries in

\footnotetext{
${ }^{10}$ Weights are equal to the number of subsidiaries in each country. Data on subsidiaries come from Dyreng \& Lindsey (2009).
} 
which the firm discloses subsidiaries (GOVT_STAB), as shown in Model 2, is also positive and significant, indicating that international diversification in countries with a more stable government leads to more socially responsible behavior by U.S. multinational firms, and thus a higher CSR rating. In Models 3-7 of Table 10 we compute the weighted average of, respectively, the government's investment profile rating, control of corruption rating, law-and-order rating, democratic accountability rating, and quality of bureaucracy rating. Interestingly, the estimated coefficient on each of these factors loads significantly positively on CSR, providing evidence that multinational firms with subsidiaries in countries with strong legal and political institutions are associated with a higher CSR rating. Moreover, the effect on CSR rating of our key variable (FS/S) continues to hold, lending further weight to our main finding on the societal implications of geographic diversification.

In sum, the evidence reported in Table 10 lends weight to our fourth hypothesis $\left(H_{4}\right)$. Taken together, our novel evidence on the firm-level CSR implications of the institutional environments in which the firm's subsidiaries are located complements Ioannou \& Serafeim’s (2012) findings that country institutions are important determinants of firms' social and environmental performance.

Table 10 goes here

\subsection{Internationalization and CSR: The Conditioning Role of Firm Characteristics}

To supplement our analysis, we assess whether the importance of internationalization to CSR activities varies systematically with firm characteristics. To do so we re-estimate Equation (1) 
(Model 1 in Table 4) after bisecting the sample according to the median firm characteristics. The firm characteristics we analyze are firm size (SIZE), firm age ( $\left.L O G \_A G E\right)$, return on assets ( $R O A)$, market-to-book (MTB), leverage ( $L E V), \mathrm{R} \& \mathrm{D}$ expenditures $(R \& D / S)$, and advertising intensity $(A D V / S)$. The results are reported in Table 11.

We start by splitting our sample into two subsamples based on firm size. We then run our main regression separately for the small (Model 1) and large (Model 2) firms. All else being equal, large firms are more able to cope with the complexity and uncertainty of internationally diversified operations than small firms, because their diversity of activities, stability of cash flows, and abundance of resources enables them to more easily support global expansion and exploit economies of scale (e.g., Dunning, 1993; Fatemi, 1984; Kotabe, 1990; Singh \& Montgomery, 1987). ${ }^{11}$ Further, Kirca, Hult, Deligonul, Perry, \& Cavusgil (2012: 59) argue that the benefits of scale are more pronounced for larger firms because they have access "to privileged learning channels, they can reduce risk through wider portfolios, and they have stronger bargaining power to gain concessions from host country institutions and governments”. Not surprisingly, therefore, the regression results reported in Models 1 and 2 of Table 11 indicate that internationalization is positively related to CSR only in large firms. Indeed, the estimated coefficient on FS/S for small firms is negative and insignificant, but positive and significant at the 5 percent level for large firms. Thus, internationalization seems to have societal implications only for large firms. This finding may be driven by large firms being more capable of taking proactive steps to create and preserve their competitive advantage than small firms (e.g., Gaba, Pan, \& Ungson, 2002). This result is in line with the resource-based theory that stresses a firm's

\footnotetext{
${ }^{11}$ The empirical findings of Tallman \& Li (1996), Tihanyi, Johnson, Hoskisson, \& Hitt (2003), and Kirca, Hult, Deligonul, Perry, \& Cavusgil (2012), among many others, support the positive association between international diversification and firm size.
} 
core resources and capabilities as drivers of the firm's competitive advantage (e.g., Hsu \& Pereira, 2008).

Next, we split our sample into two subsamples based on firm age. The results, reported in Models 3 and 4 of Table 11, suggest that the positive link between internationalization and CSR only pertains for mature firms. Older firms may be more likely than younger firms to invest strategically in CSR when expanding their operations internationally as they are more likely to have the managerial experience and resources necessary to manage the complexity and challenges that arise from internationalization (Kirca Hult, Deligonul, Perry, \& Cavusgil, 2012).

Turning to the conditioning effect of firm performance, the results reported in Models 5 and 6 suggest that the societal implications of internationalization appear to concentrate among firms with good profitability as measured by average ROA over the past three years. Indeed, while the estimated coefficient on FS/S does not have any significant effect on the CSR rating of firms with poor performance, it is positive and statistically significant at the 1 percent level for firms with good operating performance. This suggests that firms with good performance that expand internationally are more likely to engage in CSR activities than firms with poor performance. This result corroborates the findings of Dunning (1993), Geringer, Beamish, \& DaCosta (1989), and Goerzen \& Beamish (2003) that performance increases with international diversification. More profitable multinational firms have more flexibility in spreading fixed costs, accessing resources, and optimizing organizational learning (Goerzen \& Beamish, 2003), and thus are more likely to adopt social behaviors that meet the expectations of stakeholders associated with their foreign activities. 


\section{Table 11 goes here}

Given that growth opportunities are among the driving forces behind internationalization, we next split our sample based on a firm's market-to-book value of assets. By comparing the estimated coefficient on FS/S in Models 7 and 8, we see that internationalization increases CSR only in high growth firms. This finding, in line with the evidence of Gande, Schenzler, \& Senbet (2009) that global diversification enhances firm value, suggests that poor growth opportunities may constrain firms' strategic initiatives (e.g., limit their CSR investment), which limits the potential to expand into new foreign markets. By contrast, firms with more growth opportunities are more likely to have adequate resources to pursue strategies (e.g., CSR) to increase and maintain their competitive position in the global market. When we split our sample based on firm leverage in Models 9 and 10, we do not find any distinguishable difference between the two subsamples with respect to the implication of internationalization for CSR.

The findings of Table 11 so far (SIZE, LOG_AGE, ROA, MTB, and LEV) largely support the resource-based view of the firm, suggesting that firms with abundant resources are more likely to succeed in expanding business globally than firms with fewer resources. These resources and capabilities can help firms pursue strategies such as CSR to increase their competitive advantage (Chandler \& Hanks, 1994). As a result, high CSR firms can better cope with not only an increasing geographical scope of operations and changing business environment, but also new and more diverse stakeholders, and thus increase their competitive advantage, than low CSR firms. This conclusion is strongly supported by the findings reported in Models 11 and 12 for $R \& D / S$ and Models 13 and 14 for $A D V / S$. Indeed, these results suggest that 
firms with high R\&D intensity or high advertising intensity ${ }^{12}$ are more likely to invest in CSR to strengthen the competitive position of their global diversification than firms with low R\&D or advertising. This evidence is consistent with Morck \& Yeung (1998), who suggest that information-based assets related to $R \& D$ and advertising enhance the value of geographic diversification. Such investments can create firm-specific, valuable, inimitable, and nonsubstitutable resources that lead to competitive advantage (Barney, 1991; Morck \& Yeung, 1991, among others).

In sum, the evidence in Table 11 supports existing findings, as reported in Hitt, Tihanyi, Miller, and Connelly's (2006) survey, that global diversification is positively related to R\&D intensity, size, performance, product diversification, and organizational age.

\section{CONCLUSION}

In this paper we examine the importance of CSR as a strategic response to the uncertainty and complexity associated with expanding firm operations internationally. Our premise is rooted in the view that stakeholders' perception of a firm’s social reputation affects the success or failure of the firm in an international setting (Brammer, Pavelin, \& Porter, 2009).

Using the largest sample to date in the context of the internationalization-CSR relation, we find that global diversification appears to exert a significant and consistent positive effect on CSR. We also find that internationalization bears significantly only on those CSR dimensions that are discretionary in nature and less likely to be determined by societal and legal requirements, and that firm internationalization loads significantly (and positively) on CSR

\footnotetext{
${ }^{12}$ This finding is also consistent with evidence in Servaes \& Tamayo (2013) that CSR activities can improve value for firms with high advertising intensity, while the effect is either insignificant or negative for firms with low advertising intensity.
} 
strengths but not CSR concerns. We further find that only multinational firms that have more abundant resources increase their CSR investments in response to their internationalization. This result substantiates the resource-based theory that stresses a firm's core resources and capabilities as drivers of the firm's competitive advantage in international diversification. We also provide new evidence that multinational firms with subsidiaries in countries with strong institutional environments and strong legal and political institutions are associated with higher CSR ratings. In sum, our findings support the view that CSR can strengthen firms' competitive position globally, and highlight CSR as a channel for multinational firms to achieve the benefits of internationalization.

The findings of this study invite future researchers to explore the implications of the internationalization-CSR link on other corporate outcomes, while taking into account the institutional and political environments where subsidiaries of multinational firms operate. For practitioners and regulators, this study suggests that an effective way to enhance the value of international diversification is to provide firms with incentives to enhance their CSR rating. 


\section{References}

Andersen, O. "On the Internationalization Process of Firms: A Critical Analysis." Journal of International Business Studies, (1993): 24: 209-231.

Attig, N.” Intangible Assets, Organizational Capital and Corporate Social Responsibility: Evidence from U.S. Manufacturing Firms.” Working paper, Saint Mary’s University, 2011.

Attig, N., El Ghoul, S., Guedhami, O., \& Cleary, S. "Corporate Legitimacy and Investment-Cash Flow Sensitivity.” Journal of Business Ethics, (2013): forthcoming.

Attig N., El Ghoul, S., Guedhami, O., \& Suh, J. "Corporate Social Responsibility and Credit Ratings.” Journal of Business Ethics, (2013): forthcoming.

Bae, K-H., Kang, J-K., \& Wang, J. "Employee Treatment and Firm Leverage: A Test of the Stakeholder Theory ff Capital Structure.” Journal of Financial Economics, (2011): 100: 130-153.

Barney, J. B. "Firm Resources and Sustained Competitive Advantage.” Journal of Management, (1991): 17: 99-120.

Benabou, R., \& Tirole, J. “Individual and Corporate Social Responsibility.” Economica, (2010): 77(305): $1-19$.

Brammer, S. J., Pavelin S., \& Porter, L. A. "Corporate Social Performance and Geographical Diversification.” Journal of Business Research, (2006): 59: 1025-1034.

Brammer, S. J., Pavelin S., \& Porter, L. A. "Corporate Charitable Giving, Multinational Companies and Countries of Concern.” Journal of Management Studies, (2009) : 46: 575-596.

Campbell, J. L. "Why Would Corporations Behave in Socially Responsible Ways? An Institutional Theory of Corporate Social Responsibility.” Academy of Management Review, (2007): 32: 946967.

Carroll, A. "A Three-Dimensional Conceptual Model of Corporate Social Performance.” Academy of Management Review, (1979): 4: 497-505.

Chandler, G., \& Hanks, S. H. "Founder Competence, the Environment, and Venture Performance." Entrepreneurship Theory and Practice, (1994): 18: 77-89.

Chatterji, A. K., Levine, D. I., \& Toffel, M. W. "How Well Do Social Ratings Actually Measure Corporate Social Responsibility?” Journal of Economics and Management Strategy, (2009): 18: 125-169.

Dhaliwal, D., Li, O. Z., Tsang, A. H, \& Yang, Y. G. "Voluntary Nonfinancial Disclosure and the Cost of Equity Capital: The Initiation of Corporate Social Responsibility Reporting.” The Accounting Review, (2011): 86: 59-100

Dunning, J. H. "Multinational Enterprises and the Global Economy.” Wokingham, UK: Addison Wesley, 1993.

Dyreng S., Hanlon, M., \& Maydew, E. “Where Do Firms Manage Earnings?” Review of Accounting Studies, (2012): 17: 649-687.

Dyreng, S., \& Lindsey, B. "Using Financial Accounting Data to Examine the Effect of Foreign Operations Located in Tax Havens and Other Countries On U.S. Multinational Firms' Tax Rates.” Journal of Accounting Research, (2009): 47: 1283-1316.

El Ghoul, S., Guedhami, O., Kwok, C. C., \& Mishra, D. "Does Corporate Social Responsibility Affect the Cost of Capital?” Journal of Banking and Finance, (2011): 35: 2388-2406.

Fama, E. F., \& French, K. R. "Industry Costs of Equity.” Journal of Financial Economics, (1997): 43: 153-194.

Fatemi, A. M. "Shareholder Benefits from Corporate International Diversification.” Journal of Finance, (1984): 39: 1325-1344.

Feldman, S. J., Soyka, P. A., \& Ameer, P. “Does Improving a Firm’s Environmental Management System and Environmental Performance Result in a Higher Stock Price?” Journal of Investing, (1997): 6: 87-97. 
Figge, F., Han, T., Schaltegger, S., \& Wagner, M. “The Sustainability Balanced Scorecard: Linking Sustainability Management to Business Strategy.” Business Strategy and the Environment, (2002): 11: 269-284.

Gaba, V., Pan, Y., \& Ungson, G. R. "Timing of Entry in International Market: An Empirical Study of U.S. Fortune 500 Firms in China.” Journal of International Business Studies, (2002): 33: 39-55.

Galema, R., Plantinga, A., \& Scholtens, B. "The Stocks at Stake: Return and Risk in Socially Responsible Investment.” Journal of Banking and Finance, (2008): 32: 2646-2654.

Gande, A., Schenzler C., \& Senbet, L. W. "Valuation Effects of Global Diversification.” Journal of International Business Studies, (2009): 40: 1515-1532.

Geringer, J. M., Beamish, P. W., \& DaCosta, R. C. "Diversification Strategy and Internationalization: Implication for MNE Performance.” Strategic Management Journal, (1989): 10: 109-119.

Goerzen, A., \& Beamish, P. W. “Geographic Scope and Multinational Enterprise Performance.” Strategic Management Journal, (2003): 24: 1289-1306.

Goss, A., \& Roberts, G. S. "The Impact of Corporate Social Responsibility on the Cost of Bank Loans.” Journal of Banking and Finance, (2011): 35: 1794-1810.

Gow, I. D., Ormazabal, G., \& Taylor, D. J. "Correcting for Cross-Sectional and Time-Series Dependence In Accounting Research.” The Accounting Review, (2010): 85, 483-512.

Griffin, J. J., \& Mahon, J. F. "The Corporate Social Performance and Corporate Financial Performance Debate.” Business \& Society, (1997): 36: 5-31.

Hart, S. L. "A Natural-Resource-Based View of the Firm.” Academy of Management Review, (1995): 20: 986-1014.

Hillman, A. J., \& Keim, J. D. "Shareholder Value, Stakeholder Management, and Social Issues: What's the Bottom Line?” Strategic Management Journal, (2001): 22: 125-139.

Hitt, M. A., Hoskisson, R. E., \& Kim, H. "International Diversification: Effects on Innovation and Firm Performance in Product-Diversified Firms.” Academy of Management Journal, (1997): 40: 767798.

Hitt, M. A., Ireland, R. D., \& Hoskisson, R. E. "Strategic Management: Competitiveness and Globalization.” Mason, OH: South-Western, 2007.

Hitt, M. A., Tihanyi, L., Miller, T., \& Connelly, B. "International Diversification: Antecedents, Outcomes, and Moderators.” Journal of Management, (2006): 32: 831-867.

Hong, H., \& Kacperczyk, M. "The Price of Sin: The Effects of Social Norms on Markets." Journal of Financial Economics, (2009): 93: 15-36.

Hsu, C-C., \& Pereira, A. "Internationalization and Performance: The Moderating Effects of Organizational Learning.” Omega, (2008): 36: 188-205.

Ioannou, I., \& Serafeim, G. "What Drives Corporate Social Performance? The Role of Nation-Level Institutions.” Journal of International Business Studies, (2012): 43: 834-864.

Johanson, J., \& Vahlne, J.-E. "The Internationalization Process of the Firm: A Model of Knowledge Development and Increasing Foreign Market Commitments.” Journal of International Business Studies, (1977): 8: 23-32.

Kang, J. "The Relationship between Corporate Diversification and Corporate Social Performance." Strategic Management Journal, (2013): 34: 94-109.

Kim, Y., Park, M. S., \& Wier, B. “Is Earnings Quality Associated with Corporate Social Responsibility?” The Accounting Review, (2012): 87: 761-796.

Kirca, H. A., Hult, G. T. M., Deligonul, S., Perry, M. Z., \& Cavusgil, S. T. “A Multilevel Examination of the Drivers of Firm Multinationality: A Meta-analysis.” Journal of Management, (2012): 38: 502530.

Kogut, B. "Designing Global Strategies: Profiting from Operational Flexibility." Sloan Management Review, (1985): 21: 27-38.

Kostova, T., \& Zaheer, S. "Organizational Legitimacy under Conditions of Complexity: The Case of Multinational Enterprise.” Academy of Management Review, (1999): 24: 64-81. 
Kotabe, M. "The Relationship between Offshore Sourcing and Innovativeness of U.S. Multinational Firms: An Empirical Investigation.” Journal of International Business Studies, (1990): 21: 623638.

La Porta, R., Lopez-de-Silanes, F., Shleifer, A., \& Vishny, R. W. “Law and Finance.” Journal of Political Economy, (1998): 106: 1113-1155.

Maksimovic, V., \& Titman, S. “Financial Policy and a Firm’s Reputation for Product Quality.” Review of Financial Studies, (1991): 2:175-200.

Margolis, J. D., \& Walsh, J. P. "Misery Loves Companies: Rethinking Social Initiatives by Business.” Administrative Science Quarterly, (2003): 48: 268-305.

McWilliams, A., \& Siegel, D. "Corporate Social Responsibility: A theory of the Firm Perspective." Academy of Management Review, (2001): 28: 117-127.

Morck, R., \& Yeung, B. “Why Investors Value Multinationality?” Journal of Business, (1991): 64: 165187.

Morck, R., \& Yeung, B. "Why Investors Sometimes Value Size and Diversification: The Internalization Theory on Synergy.” Working paper, Institute for Financial Research, University of Alberta, 1998.

Murtha, P. T., \& Lenway, S. A. "Country Capabilities and the Strategic State: How National Political Institutions Affect Multinational Corporations' Strategies.” Strategic Management Journal, (1994): 15: 113-129.

Nachum, L., \& Zaheer, A. “The Persistence of Distance? The Impact of Technology on MNE Motivations for Foreign Investment.” Strategic Management Journal, (2005): 26, 747-767.

Orlitzky, M., Siegel, D. S., \& Waldman, D. A. "Strategic Corporate Social Responsibility and Environmental Sustainability.” Business \& Society, (2011): 50: 6-27.

Petersen, M. A. "Estimating Standard Errors in Finance Panel Data Sets: Comparing Approaches” Review of Financial Studies, (2009): 22: 435-480.

Porter, M. E. “The Competitive Advantage of Nations.” New York: Free Press, 1990.

Riahi-Belkaoui, A. "Level of Multinationality, Growth Opportunities and Size as Determinants of Analyst’s Ratings of Corporate Disclosures.” American Business Review, (2001): 19: 1-6.

Roberts, R. "Determinants of Corporate Social Responsibility Disclosure: An Application of Stakeholder Theory.” Accounting, Organizations and Society, (1992): 17: 595-612.

Rosenbaum, P., \& Rubin, D. "The Central Role of the Propensity Score in Observational Studies for Causal Effects.” Biometrika, (1983): 70: 41-55.

Servaes, H., \& Tamayo, A. "The Impact of Corporate Social Responsibility on Firm Value: The Role of Customer Awareness.” Management Science, (2013): forthcoming.

Sharfman, M. P., Shaft T. M., \& Tihanyi, L. "A Model of Global And Institutional Antecedents Of HighLevel Corporate Environmental Performance.” Business Society, (2004): 43: 6-36.

Simerly, R. L. "Corporate Social Performance and Multinationality: An Empirical Examination." International Journal of Management, (1997): 14: 699-703.

Simerly, R. L., \& Li, M. "Corporate Social Performance and Multinationality, A Longitudinal Study.” Working paper, (2000): http:www.westga.edu/ bquest/2000/corporate.html

Singh, H., \& Montgomery, C. A. "Corporate Acquisition Strategies and Economic Performance." Strategic Management Journal, (1987): 8: 377-386.

Strike, M. V., Gao, J., \& Bansal, P. "Being Good While Being Bad: Social Responsibility and the International Diversification of US Firms.” Journal of International Business Studies, (2006): 37: 254-280.

Tallman, S., \& Li, J. "Effects of International Diversity and Product Diversity on the Performance of Multinational Firms.” Academy of Management Journal, (1996): 39, 179-196.

Tihanyi, L., Johnson, R. A., Hoskisson, R. E., \& Hitt, M. A. "Institutional Ownership Differences and International Diversification: The Effects of Boards of Directors and Technological Opportunity." Academy of Management Journal, (2003): 46: 195-211. 
Waddock, S. A., \& Graves, S. B. “The Corporate Social Performance-Financial Performance Link.” Strategic Management Journal, (1997): 18: 303-319.

Zaheer, S. "Overcoming the Liability of Foreignness." Academy of Management Journal, (1995): 38 : 341-363.

Zahra, S. A., \& Garvis, D. M. "International Corporate Entrepreneurship and Firm Performance: The Moderating Effect of International Environment Hostility.” Journal of Business Venturing, (2000): 15: 469-492.

Zahra, S. A., Ireland, R. D., \& Hitt, M. A. "International Expansion by New Venture Firms: International Diversity, Mode of Market Entry, Technological Learning, and Performance.” Academy of Management Journal, (2000): 43: 925-950. 


\section{Appendix A}

Qualitative Issue Area Definitions

We consider six qualitative issue areas: Community, Diversity, Employee Relations, Environment, Human Rights, and Product Characteristics. Each area has a set of strengths and concerns as illustrated below. We calculate a score for each area equal to the number of strengths minus the number of concerns. We also calculate an overall CSR score equal to the sum of all areas' scores.

\begin{tabular}{|c|c|c|}
\hline & Concerns & Strengths \\
\hline \multirow{8}{*}{ Community } & Investment Controversies & Charitable Giving \\
\hline & Negative Economic Impact & Innovative Giving \\
\hline & Indigenous Peoples Relations & Non-US Charitable Giving \\
\hline & Tax Disputes & Support for Housing \\
\hline & Other Concern & Support for Education \\
\hline & & Indigenous Peoples Relations \\
\hline & & Volunteer Programs \\
\hline & & Other Strength \\
\hline \multirow{8}{*}{ Diversity } & Controversies & CEO \\
\hline & Non-Representation & Promotion \\
\hline & Other Concern & Board of Directors \\
\hline & & Work/Life Benefits \\
\hline & & Women \& Minority Contracting \\
\hline & & Employment of the Disabled \\
\hline & & Gay \& Lesbian Policies \\
\hline & & Other Strength \\
\hline \multirow{7}{*}{ Employee Relations } & Union Relations & Union Relations \\
\hline & Health and Safety Concern & No-Layoff Policy \\
\hline & Workforce Reductions & Cash Profit Sharing \\
\hline & Retirement Benefits Concern & Employee Involvement \\
\hline & Other Concern & Retirement Benefits Strength \\
\hline & & Health and Safety Strength \\
\hline & & Other Strength \\
\hline \multirow[t]{7}{*}{ Environment } & Hazardous Waste & Beneficial Products and Services \\
\hline & Regulatory Problems & Pollution Prevention \\
\hline & Ozone Depleting Chemicals & Recycling \\
\hline & Substantial Emissions & Clean Energy \\
\hline & Agricultural Chemicals & Communications \\
\hline & Climate Change & Property, Plant, and Equipment \\
\hline & Other Concern & Other Strength \\
\hline \multirow[t]{7}{*}{ Human rights } & South Africa & Positive Record in South Africa \\
\hline & Northern Ireland & Indigenous Peoples Relations Strength \\
\hline & Burma Concern & Labor Rights Strength \\
\hline & Mexico & Other Strength \\
\hline & Labor Rights Concern & \\
\hline & Indigenous Peoples Relations Concern & \\
\hline & Other Concern & \\
\hline \multirow[t]{4}{*}{ Product characteristics } & Product Safety & Quality \\
\hline & Marketing/Contracting Concern & R\&D/Innovation \\
\hline & Antitrust & Benefits to Economically Disadvantaged \\
\hline & Other Concern & Other Strength \\
\hline
\end{tabular}




\section{Appendix B}

\section{Variable Definitions and Data Sources}

\begin{tabular}{|c|c|c|}
\hline Variable & Definition & Source \\
\hline \multicolumn{3}{|c|}{ Panel A. Corporate social responsibility variables } \\
\hline CSR_COM_S & $\begin{array}{l}\text { The Community score equals the number of strengths minus the number of } \\
\text { concerns in the Community qualitative issue area }\end{array}$ & $\begin{array}{l}\text { Authors' calculations } \\
\text { based on MSCI ESG } \\
\text { STATS data }\end{array}$ \\
\hline CSR_DIV_S & $\begin{array}{l}\text { The Diversity score equals the number of strengths minus the number of concerns in } \\
\text { the Diversity qualitative issue area }\end{array}$ & As above \\
\hline CSR_EMP_S & $\begin{array}{l}\text { The Employee Relations score equals to the number of strengths minus the number } \\
\text { of concerns in the Employee Relations qualitative issue area }\end{array}$ & As above \\
\hline CSR_ENV_S & $\begin{array}{l}\text { The Environment score equals the number of strengths minus the number of } \\
\text { concerns in the Environment qualitative issue area }\end{array}$ & As above \\
\hline CSR_HUM_S & $\begin{array}{l}\text { The Human Rights score equals the number of strengths minus the number of } \\
\text { concerns in the Human Rights qualitative issue area. }\end{array}$ & As above \\
\hline CSR_PRO_S & $\begin{array}{l}\text { The Product score equals the number of strengths minus the number of concerns in } \\
\text { the Product qualitative issue area }\end{array}$ & As above \\
\hline CSR_S & $\begin{array}{l}\text { The CSR score equals the sum of the Community, Diversity, Employee, } \\
\text { Environment, Human Rights, and Product Characteristics qualitative issue areas } \\
\text { scores }\end{array}$ & As above \\
\hline CSR_STR & $\begin{array}{l}\text { The total number of strengths of the Community, Diversity, Employee, } \\
\text { Environment, Human Rights, and Product Characteristics qualitative issue areas }\end{array}$ & As above \\
\hline CSR_CON & $\begin{array}{l}\text { The total number of concerns of the Community, Diversity, Employee, } \\
\text { Environment, Human Rights, and Product Characteristics qualitative issue areas }\end{array}$ & As above \\
\hline \multicolumn{3}{|c|}{ Panel B. Control variables } \\
\hline$F S / S$ & $\begin{array}{l}\text { Ratio of foreign sales to total sales, where foreign sales are defined as the sum of } \\
\text { sales of all foreign segments. }\end{array}$ & $\begin{array}{l}\text { Authors' calculations } \\
\text { based on Compustat data }\end{array}$ \\
\hline$F A / A$ & $\begin{array}{l}\text { Ratio of foreign assets to total assets, where foreign assets are defined as the sum of } \\
\text { assets of all foreign segments }\end{array}$ & As above \\
\hline HERFINDAHL_S & $\begin{array}{l}\text { For a firm with } \mathrm{N} \text { geographic segments, the sales Herfindahl index is defined as } \\
\sum_{i=1}^{N}\left(s_{i} / \sum_{i=1}^{N} s_{i}\right)^{2} \text {, where } s_{i} \text { stands for geographic segment's } i \text { sales }\end{array}$ & As above \\
\hline HERFINDAHL_A & $\begin{array}{l}\text { For a firm with } N \text { geographic segments, the assets Herfindahl index is defined as } \\
\sum_{i=1}^{N}\left(a_{i} / \sum_{i=1}^{N} a_{i}\right)^{2} \text {, where } a_{i} \text { stands for geographic segment's } i \text { assets }\end{array}$ & As above \\
\hline ENTROPY_S & $\begin{array}{l}\text { For a firm with } N \text { geographic segments, the sales entropy index is defined as } \\
-\sum_{i=1}^{N}\left(s_{i} / \sum_{i=1}^{N} s_{i}\right) \cdot \ln \left(s_{i} / \sum_{i=1}^{N} s_{i}\right) \text {, where } s_{i} \text { stands for geographic segment's } i \\
\text { sales }\end{array}$ & As above \\
\hline ENTROPY_A & $\begin{array}{l}\text { For a firm with } N \text { geographic segments, the assets entropy index is defined as } \\
-\sum_{i=1}^{N}\left(a_{i} / \sum_{i=1}^{N} a_{i}\right) \cdot \ln \left(a_{i} / \sum_{i=1}^{N} a_{i}\right) \text {, where } a_{i} \text { stands for geographic segment's } i \\
\text { assets }\end{array}$ & As above \\
\hline SIZE & Firm size measured as the logarithm of total sales & As above \\
\hline$L O G \_A G E$ & $\begin{array}{l}\text { Logarithm of firm age defined as the number of months since the firm first appeared } \\
\text { in the CRSP database }\end{array}$ & $\begin{array}{l}\text { Authors' calculations } \\
\text { based on CRSP data }\end{array}$ \\
\hline ROA & Return on assets defined as the ratio of EBITDA to total assets. & $\begin{array}{l}\text { Authors' calculations } \\
\text { based on Compustat data }\end{array}$ \\
\hline MTB & $\begin{array}{l}\text { The market-to-book ratio of assets is defined as the ratio of the market value of } \\
\text { assets to the book value of assets, where the market value of assets is measured as } \\
\text { market capitalization (number of shares outstanding } \times \text { share price) minus the book } \\
\text { value of equity plus the book value of assets. }\end{array}$ & As above \\
\hline$L E V$ & Leverage ratio defined as the ratio of total debt to total assets & As above \\
\hline$R \& D / S$ & $\begin{array}{l}\text { Ratio of research and development expenses to total sales. This ratio is set to zero } \\
\text { when research and development expenses are missing. }\end{array}$ & As above \\
\hline$A D V / S$ & $\begin{array}{l}\text { Ratio of advertising expenses to total sales. This ratio is set to zero when advertising } \\
\text { expenses are missing. }\end{array}$ & As above \\
\hline \multicolumn{3}{|c|}{ Panel C. Instrumental variables } \\
\hline MID & $\begin{array}{l}\text { Dummy variable set to } 1 \text { if the firm reports minority interest on its balance sheet, } \\
\text { and } 0 \text { otherwise. }\end{array}$ & As above \\
\hline PNFOR & The fraction of firms with positive FS/S in the firm's industry in a given year. & As above \\
\hline STATE_FS/S & $\begin{array}{l}\text { The ratio of foreign sales of all firms headquartered in the state to foreign sales of } \\
\text { all sample firms in a given year. }\end{array}$ & As above \\
\hline
\end{tabular}


Panel D. Institutional environment variables

POLIT_RISK Weighted average political risk rating of countries in which the firm discloses subsidiaries in Exhibit 21 of Form 10-K. Weights are equal to the number of subsidiaries in each country.

GOVT_STAB

Weighted average government stability rating of countries in which the firm discloses subsidiaries in Exhibit 21 of Form 10-K. Weights are equal to the number of subsidiaries in each country.

INV_PROFILE Weighted average government investment profile of countries in which the firm discloses subsidiaries in Exhibit 21 of Form 10-K. Weights are equal to the number of subsidiaries in each country.

CORRUPT Weighted average corruption control rating of countries in which the firm discloses subsidiaries in Exhibit 21 of Form 10-K. Weights are equal to the number of subsidiaries in each country.

LAW_ORDER Weighted average law and order rating of countries in which the firm discloses subsidiaries in Exhibit 21 of Form 10-K. Weights are equal to the number of subsidiaries in each country.

DEMOC Weighted average democratic accountability rating of countries in which the firm discloses subsidiaries in Exhibit 21 of Form 10-K. Weights are equal to the number of subsidiaries in each country.

BUREAUCR Weighted average quality of bureaucracy rating of countries in which the firm discloses subsidiaries in Exhibit 21 of Form 10-K. Weights are equal to the number of subsidiaries in each country.

Authors' calculations based on International Country Risk Guide data and Dyreng and

Lindsey’s (2009) data.

As above

As above

As above

As above

As above

As above 
TABLE 1

Sample Breakdown by Industry and Year

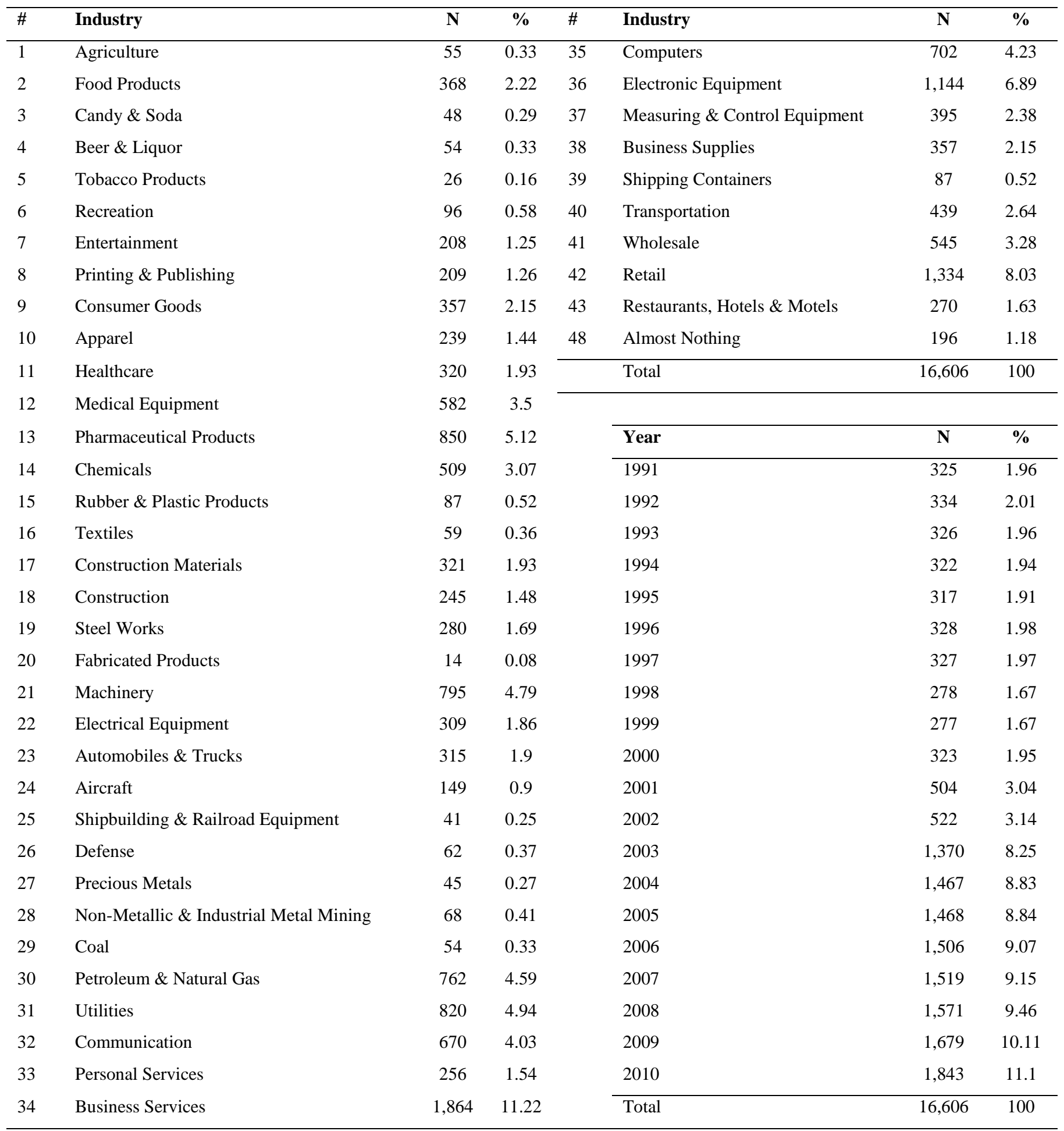

Notes: This table presents the industry (according to the 48 industry group affiliations in Fama \& French, 1997) and calendar year distributions for the 16,606 firm-year observations representing 3,040 unique firms used in the hypothesis tests. 
TABLE 2

Descriptive Statistics for Corporate Social Responsibility Data by Year

\begin{tabular}{|c|c|c|c|c|c|c|c|}
\hline \multicolumn{8}{|c|}{ Panel A. Descriptive statistics for the CSR score by year } \\
\hline Year & Mean & Min & Q1 & Median & Q3 & Max & SD \\
\hline 1991 & 0.35 & -8 & 0 & 0 & 1 & 5 & 1.93 \\
\hline 1992 & 0.34 & -7 & -1 & 0 & 2 & 7 & 2.15 \\
\hline 1993 & 0.25 & -7 & -1 & 0 & 2 & 7 & 2.44 \\
\hline 1994 & 0.39 & -7 & -1 & 0 & 2 & 8 & 2.56 \\
\hline 1995 & 0.81 & -7 & -1 & 1 & 2 & 11 & 2.58 \\
\hline 1996 & 0.84 & -6 & -1 & 0.5 & 2 & 9 & 2.37 \\
\hline 1997 & 0.82 & -7 & -1 & 0 & 2 & 10 & 2.48 \\
\hline 1998 & 0.87 & -7 & -1 & 1 & 2 & 9 & 2.41 \\
\hline 1999 & 0.90 & -7 & -1 & 1 & 2 & 11 & 2.66 \\
\hline 2000 & 0.86 & -6 & -1 & 1 & 2 & 11 & 2.57 \\
\hline 2001 & 0.41 & -9 & -1 & 0 & 2 & 9 & 2.28 \\
\hline 2002 & 0.42 & -9 & -1 & 0 & 2 & 9 & 2.42 \\
\hline 2003 & -0.24 & -9 & -1 & 0 & 0 & 8 & 1.76 \\
\hline 2004 & -0.44 & -8 & -1 & -1 & 0 & 10 & 1.83 \\
\hline 2005 & -0.41 & -8 & -1 & -1 & 0 & 11 & 1.98 \\
\hline 2006 & -0.39 & -7 & -2 & -1 & 0 & 15 & 2.18 \\
\hline 2007 & -0.41 & -8 & -2 & -1 & 1 & 14 & 2.24 \\
\hline 2008 & -0.43 & -9 & -2 & -1 & 1 & 13 & 2.22 \\
\hline 2009 & -0.46 & -9 & -2 & -1 & 1 & 13 & 2.25 \\
\hline 2010 & -0.52 & -7 & -2 & -1 & 0 & 14 & 2.68 \\
\hline All years & -0.17 & -9 & -2 & 0 & 1 & 15 & 2.29 \\
\hline
\end{tabular}

Panel B. Mean of the total number of strengths, total number concerns and individual components of the CSR score by year

\begin{tabular}{|c|c|c|c|c|c|c|c|c|}
\hline Year & 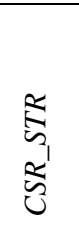 & 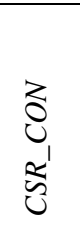 & 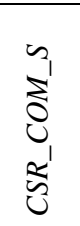 & 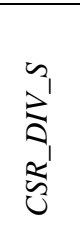 & 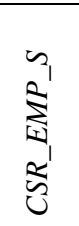 & 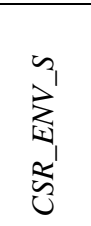 & 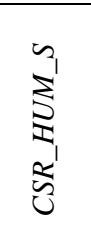 & 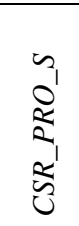 \\
\hline 1991 & 1.24 & 0.90 & 0.26 & 0.23 & 0.14 & -0.11 & . & -0.01 \\
\hline 1992 & 1.46 & 1.12 & 0.29 & 0.29 & 0.10 & -0.17 & . & 0.00 \\
\hline 1993 & 1.67 & 1.42 & 0.33 & 0.09 & 0.14 & -0.16 & . & 0.04 \\
\hline 1994 & 2.02 & 1.62 & 0.41 & 0.14 & 0.13 & -0.23 & . & 0.03 \\
\hline 1995 & 2.24 & 1.43 & 0.44 & 0.35 & 0.21 & -0.14 & -0.03 & -0.02 \\
\hline 1996 & 2.12 & 1.28 & 0.41 & 0.39 & 0.18 & -0.08 & -0.01 & -0.06 \\
\hline 1997 & 2.10 & 1.29 & 0.34 & 0.44 & 0.21 & -0.07 & -0.04 & -0.06 \\
\hline 1998 & 2.12 & 1.25 & 0.22 & 0.51 & 0.31 & -0.03 & -0.06 & -0.08 \\
\hline 1999 & 2.38 & 1.48 & 0.19 & 0.67 & 0.40 & -0.20 & -0.08 & -0.08 \\
\hline 2000 & 2.42 & 1.56 & 0.20 & 0.67 & 0.44 & -0.18 & -0.09 & -0.19 \\
\hline 2001 & 1.79 & 1.38 & 0.11 & 0.60 & 0.18 & -0.20 & -0.09 & -0.18 \\
\hline 2002 & 1.90 & 1.48 & 0.12 & 0.60 & 0.16 & -0.16 & -0.09 & -0.21 \\
\hline
\end{tabular}




\begin{tabular}{lll|llllll}
2003 & 0.89 & 1.13 & 0.03 & 0.21 & -0.19 & -0.09 & -0.07 & -0.13 \\
2004 & 0.90 & 1.34 & 0.03 & 0.14 & -0.25 & -0.13 & -0.11 & -0.12 \\
2005 & 1.04 & 1.45 & 0.02 & 0.17 & -0.31 & -0.10 & -0.04 & -0.14 \\
2006 & 1.17 & 1.56 & 0.04 & 0.18 & -0.32 & -0.09 & -0.04 & -0.16 \\
2007 & 1.27 & 1.68 & 0.01 & 0.19 & -0.30 & -0.09 & -0.04 & -0.18 \\
2008 & 1.30 & 1.73 & -0.01 & 0.16 & -0.30 & -0.06 & -0.04 & -0.18 \\
2009 & 1.29 & 1.75 & -0.02 & 0.16 & -0.31 & -0.08 & -0.05 & -0.18 \\
2010 & 1.50 & 2.02 & 0.14 & -0.77 & -0.08 & 0.33 & 0.00 & -0.13 \\
\hline All years & 1.37 & 1.54 & 0.09 & 0.13 & -0.14 & -0.06 & -0.05 & -0.13 \\
\hline
\end{tabular}

Notes: This table presents descriptive statistics for the CSR data for the 16,606 firm-year observations representing 3,040 unique firms over the period 1991-2010. Panel A provides the mean, minimum, first quartile, median, third quartile, maximum and standard deviation of the overall CSR score (CSR_S) by year. Panel B shows the mean of the total number of strengths (CSR_STR), the total number of concerns (CSR_CON) and the individual components of CSR_S, namely, community relations score $\left(C S R \_C O M \_S\right)$, diversity score $\left(C S R \_D I V \_S\right)$, employee relations score $\left(C S R \_E M P \_S\right)$, environmental performance score $\left(C S R \_E N V \_S\right)$, human rights score $\left(C S R \_H U M \_S\right)$, and product characteristics score $\left(C S R \_P R O \_S\right)$. Appendix A provides details on the construction of the CSR variables. 
TABLE 3

Descriptive Statistics and Correlation Matrix for Regression Variables

\begin{tabular}{|c|c|c|c|c|c|c|c|c|c|}
\hline \multicolumn{10}{|c|}{ Panel A. Descriptive Statistics } \\
\hline & Mean & & Min & Q1 & Median & Q3 & & Max & SD \\
\hline$F S / S$ & 0.25 & & 0.00 & 0.00 & 0.16 & 0.43 & & 1.00 & 0.27 \\
\hline SIZE & 7.01 & & -4.02 & 5.89 & 7.01 & 8.16 & & 12.14 & 1.73 \\
\hline$L O G \_A G E$ & 5.19 & & 0.00 & 4.64 & 5.28 & 5.98 & & 6.93 & 1.04 \\
\hline$R O A$ & 0.12 & & -12.41 & 0.08 & 0.13 & 0.18 & & 1.39 & 0.17 \\
\hline MTB & 2.01 & & 0.77 & 1.23 & 1.59 & 2.32 & & 7.70 & 1.25 \\
\hline$L E V$ & 0.22 & & 0.00 & 0.04 & 0.20 & 0.34 & & 0.88 & 0.19 \\
\hline$R \& D / S$ & 0.07 & & 0.00 & 0.00 & 0.00 & 0.06 & & 1.76 & 0.21 \\
\hline$A D V / S$ & 0.01 & & 0.00 & 0.00 & 0.00 & 0.01 & & 0.16 & 0.03 \\
\hline \multicolumn{10}{|c|}{ Panel B. Correlation Matrix } \\
\hline & CSR_S & $F S / S$ & SIZE & $L O G \_A G E$ & $R O A$ & MTB & $L E V$ & $R \& D / S$ & $A D V / S$ \\
\hline CSR_S & 1.00 & & & & & & & & \\
\hline \multirow[t]{2}{*}{$F S / S$} & 0.09 & 1.00 & & & & & & & \\
\hline & 0.00 & & & & & & & & \\
\hline \multirow[t]{2}{*}{ SIZE } & 0.14 & 0.05 & 1.00 & & & & & & \\
\hline & 0.00 & 0.00 & & & & & & & \\
\hline \multirow{2}{*}{$L O G \_A G E$} & 0.09 & 0.03 & 0.40 & 1.00 & & & & & \\
\hline & 0.00 & 0.00 & 0.00 & & & & & & \\
\hline \multirow[t]{2}{*}{$R O A$} & 0.08 & -0.02 & 0.30 & 0.08 & 1.00 & & & & \\
\hline & 0.00 & 0.04 & 0.00 & 0.00 & & & & & \\
\hline \multirow[t]{2}{*}{ MTB } & 0.12 & 0.06 & -0.22 & -0.18 & 0.08 & 1.00 & & & \\
\hline & 0.00 & 0.00 & 0.00 & 0.00 & 0.00 & & & & \\
\hline \multirow[t]{2}{*}{$L E V$} & -0.06 & -0.15 & 0.23 & 0.08 & -0.04 & -0.24 & 1.00 & & \\
\hline & 0.00 & 0.00 & 0.00 & 0.00 & 0.00 & 0.00 & & & \\
\hline \multirow[t]{2}{*}{$R \& D / S$} & 0.02 & 0.07 & -0.44 & -0.14 & -0.48 & 0.26 & -0.10 & 1.00 & \\
\hline & 0.03 & 0.00 & 0.00 & 0.00 & 0.00 & 0.00 & 0.00 & & \\
\hline \multirow[t]{2}{*}{$A D V / S$} & 0.13 & -0.03 & 0.03 & -0.03 & 0.03 & 0.13 & -0.01 & -0.02 & 1.00 \\
\hline & 0.00 & 0.00 & 0.00 & 0.00 & 0.00 & 0.00 & 0.12 & 0.00 & \\
\hline
\end{tabular}

Notes: This table reports descriptive statistics for the regression variables. The sample is composed of 16,606 firm-year observations representing 3,040 unique firms over the period 1991-2010. FS/S is the ratio of foreign sales to total sales; SIZE is the logarithm of total sales; $L O G \_A G E$ is the logarithm of firm age defined as the number of months since the firm first appeared in the CRSP database; ROA is the ratio of EBITDA to total assets; $M T B$ is the market-to-book ratio of assets defined as the ratio of the market value of assets to the book value of assets, where the market value of assets is measured as market capitalization (number of shares outstanding $x$ share price) minus the book value of equity plus the book value of assets; $L E V$ is the leverage ratio defined as the ratio of total debt to total assets, $R \& D / S$ is the ratio of research and development expenses to total sales, and $A D V / S$ is the ratio of advertising expenses to total sales. 


\section{TABLE 4}

The Relationship between Corporate Social Responsibility and Internationalization

\begin{tabular}{|c|c|c|c|c|c|c|}
\hline & $F S / S$ & $F A / A$ & HERFINDAHL_S & HERFINDAHL_A & ENTROPY_S & ENTROPY_A \\
\hline & (1) & (2) & (3) & (4) & (5) & (6) \\
\hline$F S / S$ & $\begin{array}{c}0.531^{* * * *} \\
(3.48)\end{array}$ & & & & & \\
\hline Alternative Proxy & & $\begin{array}{c}0.417 * \\
(1.76)\end{array}$ & $\begin{array}{c}-0.473 * * * \\
(-2.81)\end{array}$ & $\begin{array}{c}-0.482 * * \\
(-2.12)\end{array}$ & $\begin{array}{c}0.211^{* *} \\
(2.35)\end{array}$ & $\begin{array}{c}0.323^{* *} \\
(2.21)\end{array}$ \\
\hline SIZE & $\begin{array}{c}0.199 * * * \\
(4.94)\end{array}$ & $\begin{array}{l}0.045 \\
(1.09)\end{array}$ & $\begin{array}{c}0.196 * * * \\
(4.70)\end{array}$ & $\begin{array}{l}0.050 \\
(1.22)\end{array}$ & $\begin{array}{c}0.199 * * * \\
(4.75)\end{array}$ & $\begin{array}{l}0.046 \\
(1.10)\end{array}$ \\
\hline$L O G \_A G E$ & $\begin{array}{c}0.082 * * \\
(2.18)\end{array}$ & $\begin{array}{l}0.071^{*} \\
(1.81)\end{array}$ & $\begin{array}{c}0.076 * * \\
(2.04)\end{array}$ & $\begin{array}{c}0.067^{*} \\
(1.68)\end{array}$ & $\begin{array}{c}0.078 * * \\
(2.08)\end{array}$ & $\begin{array}{l}0.064 \\
(1.63)\end{array}$ \\
\hline$R O A$ & $\begin{array}{c}0.567 * * \\
(2.45)\end{array}$ & $\begin{array}{l}0.255 \\
(1.23)\end{array}$ & $\begin{array}{c}0.549 * * \\
(2.29)\end{array}$ & $\begin{array}{l}0.231 \\
(1.14)\end{array}$ & $\begin{array}{c}0.548 * * \\
(2.30)\end{array}$ & $\begin{array}{l}0.227 \\
(1.13)\end{array}$ \\
\hline MTB & $\begin{array}{c}0.146^{* * *} \\
(5.45)\end{array}$ & $\begin{array}{c}0.086^{* * *} \\
(2.89)\end{array}$ & $\begin{array}{c}0.145^{* * * *} \\
(5.43)\end{array}$ & $\begin{array}{c}0.087^{* * *} \\
(3.00)\end{array}$ & $\begin{array}{c}0.146^{* * *} \\
(5.44)\end{array}$ & $\begin{array}{c}0.085^{* * *} \\
(2.96)\end{array}$ \\
\hline$L E V$ & $\begin{array}{c}-0.439 * * \\
(-2.27)\end{array}$ & $\begin{array}{c}-0.478^{* *} \\
(-2.20)\end{array}$ & $\begin{array}{c}-0.449 * * \\
(-2.32)\end{array}$ & $\begin{array}{c}-0.506^{* *} \\
(-2.35)\end{array}$ & $\begin{array}{c}-0.452 * * \\
(-2.34)\end{array}$ & $\begin{array}{c}-0.500 * * \\
(-2.32)\end{array}$ \\
\hline$R \& D / S$ & $\begin{array}{c}0.717^{* * *} \\
(3.81)\end{array}$ & $\begin{array}{l}0.341^{*} \\
(1.70)\end{array}$ & $\begin{array}{c}0.720 * * * \\
(3.78)\end{array}$ & $\begin{array}{l}0.318 \\
(1.61)\end{array}$ & $\begin{array}{c}0.725^{* * *} \\
(3.81)\end{array}$ & $\begin{array}{l}0.324 \\
(1.64)\end{array}$ \\
\hline$A D V / S$ & $\begin{array}{c}5.145^{* * * *} \\
(3.59)\end{array}$ & $\begin{array}{c}4.117^{* * *} \\
(2.74)\end{array}$ & $\begin{array}{c}5.169 * * * \\
(3.60)\end{array}$ & $\begin{array}{c}4.150 * * * \\
(2.77)\end{array}$ & $\begin{array}{c}5.256^{* * *} \\
(3.66)\end{array}$ & $\begin{array}{c}4.128 * * * \\
(2.75)\end{array}$ \\
\hline Intercept & $\begin{array}{c}-3.754 * * * \\
(-7.18)\end{array}$ & $\begin{array}{c}-2.880^{* * *} \\
(-5.44)\end{array}$ & $\begin{array}{c}-3.220 * * * \\
(-5.82)\end{array}$ & $\begin{array}{c}-2.416^{* * *} \\
(-4.14)\end{array}$ & $\begin{array}{c}-3.702 * * * \\
(-7.06)\end{array}$ & $\begin{array}{c}-2.870^{* * *} \\
(-5.47)\end{array}$ \\
\hline $\mathrm{N}$ & 16,606 & 8,316 & 16,606 & 8,234 & 16,606 & 8,234 \\
\hline Adj-R ${ }^{2}$ & 0.153 & 0.169 & 0.152 & 0.171 & 0.152 & 0.172 \\
\hline
\end{tabular}

Notes: This table reports results from regressing the CSR score (CSR_S) on proxies of internationalization and controls. The sample is composed of 16,606 firm-year observations representing 3,040 unique firms over the period 1991-2010. CSR_S equals the sum of the Community, Diversity, Employee, Environment, Human Rights, and Product Characteristics qualitative issues area scores. FS/S is the ratio of foreign sales to total sales; FA/A is the ratio of foreign assets to total assets. For a firm with $\mathrm{N}$ geographic segments, HERFINDAHL_S is defined as $\sum_{i=1}^{N}\left(s_{i} / \sum_{i=1}^{N} s_{i}\right)^{2}$, where $s_{i}$ stands for geographic segment's $i$ sales; HERFINDAHL_A is defined as $\sum_{i=1}^{N}\left(a_{i} / \sum_{i=1}^{N} a_{i}\right)^{2}$, where $a_{i}$ stands for geographic segment's $i$ assets; ENTROPY_S is defined as $-\sum_{i=1}^{N}\left(s_{i} / \sum_{i=1}^{N} s_{i}\right) \cdot \ln \left(s_{i} / \sum_{i=1}^{N} s_{i}\right)$; ENTROPY_A is defined as $-\sum_{i=1}^{N}\left(a_{i} / \sum_{i=1}^{N} a_{i}\right) \cdot \ln \left(a_{i} / \sum_{i=1}^{N} a_{i}\right)$. SIZE is the logarithm of total sales; LOG_AGE is the logarithm of firm age defined as the number of months since the firm first appeared in the CRSP database; ROA is the ratio of EBITDA to total assets; MTB is the market-to-book ratio of assets defined as the ratio of the market value of assets to the book value of assets, where the market value of assets is measured as market capitalization (number of shares outstanding $\times$ share price) minus the book value of equity plus the book value of assets; $L E V$ is the leverage ratio defined as the ratio of total debt to total assets, $R \& D / S$ is the ratio of research and development expenses to total sales, and $A D V / S$ is the ratio of advertising expenses to total sales. Industry fixed effects based on the Fama \& French (1997) industry classification and year effects are not reported to save space. Beneath each coefficient estimate is reported the t-statistic based on robust standard errors adjusted for clustering by firm. The superscript asterisks $* * *, * *$, and $*$ denote statistical significance at the $1 \%, 5 \%$, and $10 \%$ levels, respectively. 
TABLE 5

The Relationship between Corporate Social Responsibility and Internationalization over Time

\begin{tabular}{lcccc}
\hline & $1991-1995$ & $1996-2000$ & $2001-2005$ & $2006-2010$ \\
\cline { 2 - 5 }$F S / S$ & $(1)$ & $(2)$ & $(3)$ & $(4)$ \\
\cline { 2 - 5 } SIZE & 0.922 & $1.109^{* *}$ & $0.332^{*}$ & $0.620^{* * *}$ \\
& $(1.50)$ & $(2.00)$ & $(1.87)$ & $(3.65)$ \\
LOG_AGE & -0.129 & -0.065 & $0.143^{* * *}$ & $0.343^{* * *}$ \\
& $(-1.32)$ & $(-0.69)$ & $(3.21)$ & $(8.02)$ \\
$R O A$ & -0.201 & $-0.277^{* *}$ & $0.101^{* *}$ & $0.170^{* * *}$ \\
& $(-1.37)$ & $(-2.36)$ & $(2.45)$ & $(3.93)$ \\
MTB & 1.989 & $3.379^{* * *}$ & $1.404^{* * *}$ & 0.158 \\
& $(1.32)$ & $(2.73)$ & $(4.32)$ & $(1.39)$ \\
LEV & 0.066 & 0.083 & $0.108^{* * *}$ & $0.168^{* * *}$ \\
& $(0.62)$ & $(1.01)$ & $(3.79)$ & $(5.04)$ \\
$R \& D / S$ & 0.775 & 0.250 & $-0.659^{* * *}$ & $-0.453^{* *}$ \\
& $(1.09)$ & $(0.28)$ & $(-2.96)$ & $(-2.19)$ \\
ADV/S & 4.511 & -0.817 & $0.799^{* * *}$ & $0.863^{* * *}$ \\
Intercept & $(1.27)$ & $(-0.46)$ & $(4.01)$ & $(4.55)$ \\
& 1.607 & 4.025 & $7.095^{* * *}$ & $6.177^{* * *}$ \\
$\mathrm{~N}$ & $(0.51)$ & $(1.16)$ & $(4.04)$ & $(3.43)$ \\
Adj-R & 0.954 & 0.377 & $-2.612^{* * *}$ & $-5.296^{* * *}$ \\
\hline & $(0.99)$ & $(0.22)$ & $(-4.30)$ & $(-8.91)$ \\
& 1,624 & 1,533 & 5,331 & 8,118 \\
& 0.230 & 0.164 & 0.143 & 0.150 \\
\hline
\end{tabular}

Notes: This table reports results from regressing the CSR score (CSR_S) on internationalization $(F S / S)$ and controls. The sample is composed of 16,606 firm-year observations representing 3,040 unique firms over the period 1991-2010. CSR_S equals the sum of the Community, Diversity, Employee, Environment, Human Rights, and Product Characteristics qualitative issues area scores. $F S / S$ is the ratio of foreign sales to total sales. SIZE is the logarithm of total sales; LOG_AGE is the logarithm of firm age defined as the number of months since the firm first appeared in the CRSP database; ROA is the ratio of EBITDA to total assets; $M T B$ is the market-to-book ratio of assets defined as the ratio of the market value of assets to the book value of assets, where the market value of assets is measured as market capitalization (number of shares outstanding $\times$ share price) minus the book value of equity plus the book value of assets; $L E V$ is the leverage ratio defined as the ratio of total debt to total assets, $R \& D / S$ is the ratio of research and development expenses to total sales, and $A D V / S$ is the ratio of advertising expenses to total sales. Industry fixed effects based on the Fama \& French (1997) industry classification and year effects are not reported to save space. Beneath each coefficient estimate is reported the t-statistic based on robust standard errors adjusted for clustering by firm. The superscript asterisks $* * *, * *$, and $*$ denote statistical significance at the $1 \%, 5 \%$, and $10 \%$ levels, respectively. 


\section{TABLE 6}

The Relationship between Corporate Social Responsibility and Internationalization: Addressing Endogeneity

\begin{tabular}{|c|c|c|c|c|}
\hline \multicolumn{5}{|c|}{ Panel A. Instrumental Variable Regressions } \\
\hline & First-Stage & \multicolumn{3}{|c|}{ Second-Stage Regression } \\
\hline & Regression & 2 SLS & LIML & GMM \\
\hline & $(1)$ & $(2)$ & (3) & $(4)$ \\
\hline$F S / S$ & & $\begin{array}{c}0.696 * * \\
(2.08)\end{array}$ & $\begin{array}{c}0.696^{* *} \\
(2.06)\end{array}$ & $\begin{array}{c}0.733^{* *} \\
(2.20)\end{array}$ \\
\hline SIZE & $\begin{array}{c}0.024^{* * *} \\
(19.20)\end{array}$ & $\begin{array}{c}0.191 * * * \\
(4.99)\end{array}$ & $\begin{array}{c}0.191^{* * *} \\
(4.99)\end{array}$ & $\begin{array}{c}0.167^{* * *} \\
(4.43)\end{array}$ \\
\hline$L O G \_A G E$ & $\begin{array}{l}0.003^{*} \\
(1.89)\end{array}$ & $\begin{array}{l}0.067^{*} \\
(1.71)\end{array}$ & $\begin{array}{c}0.067^{*} \\
(1.71)\end{array}$ & $\begin{array}{l}0.073^{*} \\
(1.87)\end{array}$ \\
\hline$R O A$ & $\begin{array}{c}-0.034^{* * *} \\
(-2.96)\end{array}$ & $\begin{array}{c}0.653^{* *} \\
(2.57)\end{array}$ & $\begin{array}{c}0.653^{* *} \\
(2.57)\end{array}$ & $\begin{array}{c}0.654 * * \\
(2.57)\end{array}$ \\
\hline MTB & $\begin{array}{l}0.002 \\
(1.53)\end{array}$ & $\begin{array}{c}0.177^{* * * *} \\
(6.26)\end{array}$ & $\begin{array}{l}0.177^{* * *} \\
(6.26)\end{array}$ & $\begin{array}{c}0.171^{* * *} \\
(6.04)\end{array}$ \\
\hline LEV & $\begin{array}{c}-0.084 * * * \\
(-8.97)\end{array}$ & $\begin{array}{c}-0.721 * * * \\
(-3.68)\end{array}$ & $\begin{array}{c}-0.721 * * * \\
(-3.68)\end{array}$ & $\begin{array}{c}-0.596 * * * \\
(-3.11)\end{array}$ \\
\hline$R \& D / S$ & $\begin{array}{c}0.058 * * * \\
(5.85)\end{array}$ & $\begin{array}{c}0.925 * * * \\
(5.50)\end{array}$ & $\begin{array}{l}0.925 * * * \\
(5.50)\end{array}$ & $\begin{array}{c}0.827 * * * \\
(5.01)\end{array}$ \\
\hline$A D V / S$ & $\begin{array}{c}-0.208^{* * *} \\
(-3.34)\end{array}$ & $\begin{array}{c}9.538 * * * \\
(6.66)\end{array}$ & $\begin{array}{c}9.538 * * * \\
(6.66)\end{array}$ & $\begin{array}{c}9.332 * * * \\
(6.51)\end{array}$ \\
\hline MID & $\begin{array}{c}0.070^{* * *} \\
(15.71)\end{array}$ & & & \\
\hline PNFOR & $\begin{array}{c}0.459^{* * * *} \\
(74.69)\end{array}$ & & & \\
\hline STATE_FS/S & $\begin{array}{c}0.539 * * * \\
(19.15)\end{array}$ & & & \\
\hline Intercept & $\begin{array}{c}-0.236^{* * *} \\
(-18.01)\end{array}$ & $\begin{array}{c}-2.781^{* * *} \\
(-7.88)\end{array}$ & $\begin{array}{c}-2.781 * * * \\
(-7.88)\end{array}$ & $\begin{array}{c}-2.664 * * * \\
(-7.58)\end{array}$ \\
\hline $\mathrm{N}$ & 16,409 & 16,409 & 16,409 & 16,409 \\
\hline Adj- $R^{2}$ & 0.326 & 0.099 & 0.099 & 0.099 \\
\hline \multicolumn{5}{|c|}{ Panel B. Propensity Score Matching } \\
\hline \multirow{2}{*}{\multicolumn{2}{|c|}{$\begin{array}{l}\text { Matching method } \\
\text { One-to-one }\end{array}$}} & \multicolumn{3}{|c|}{ Outcome $=C S R \_S$} \\
\hline & & \\
\hline \multicolumn{2}{|l|}{ Without replacement } & \multicolumn{2}{|r|}{ (3.63) } & \\
\hline \multicolumn{2}{|l|}{ With replacement } & & $\begin{array}{c}0.367 * * * \\
(2.81)\end{array}$ & \\
\hline \multicolumn{2}{|l|}{ Caliper (3\%) } & \multicolumn{3}{|c|}{$\begin{array}{c}0.367 * * * \\
(2.81)\end{array}$} \\
\hline \multicolumn{5}{|l|}{ k-Nearest neighbors } \\
\hline \multicolumn{2}{|l|}{ Nearest neighbors $(\mathrm{n}=10)$} & \multicolumn{3}{|c|}{$\begin{array}{c}0.486 * * * \\
(4.73)\end{array}$} \\
\hline \multicolumn{2}{|l|}{ Nearest neighbors $(\mathrm{n}=50)$} & \multicolumn{3}{|c|}{$\begin{array}{c}0.570^{* * *} \\
(7.13)\end{array}$} \\
\hline \multicolumn{5}{|l|}{ Kernel } \\
\hline Gaussian kernel & & & $\begin{array}{c}0.509^{* * * *} \\
(8.85)\end{array}$ & \\
\hline Epanechnikov kernel & & & $\begin{array}{c}0.530^{* * *} \\
(7.68)\end{array}$ & \\
\hline
\end{tabular}




\begin{tabular}{|c|c|c|}
\hline \multicolumn{3}{|l|}{ Panel C. Heckman Self-Selection } \\
\hline \multirow[t]{4}{*}{ 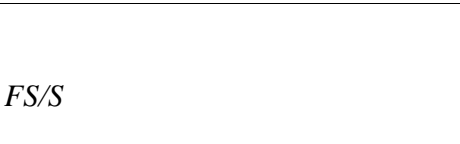 } & Selection Equation & Outcome Equation \\
\hline & $(1)$ & $(2)$ \\
\hline & & $0.677 * * *$ \\
\hline & & $(3.411)$ \\
\hline \multirow[t]{2}{*}{ SIZE } & $0.280 * * *$ & $0.201^{* * *}$ \\
\hline & $(27.028)$ & $(4.958)$ \\
\hline \multirow{2}{*}{$L O G \_A G E$} & $0.043^{* * *}$ & $0.075^{* *}$ \\
\hline & (3.099) & $(1.978)$ \\
\hline \multirow[t]{2}{*}{$R O A$} & $-0.332 * * *$ & $0.535^{* *}$ \\
\hline & $(-3.399)$ & $(2.453)$ \\
\hline \multirow[t]{2}{*}{ MTB } & $0.062 * * *$ & $0.146 * * *$ \\
\hline & $(5.261)$ & $(5.415)$ \\
\hline \multirow[t]{2}{*}{$L E V$} & $-0.326 * * *$ & $-0.472 * *$ \\
\hline & $(-4.652)$ & $(-2.430)$ \\
\hline \multirow[t]{2}{*}{$R \& D / S$} & 0.011 & $0.703^{* * *}$ \\
\hline & $(0.138)$ & $(3.741)$ \\
\hline \multirow[t]{2}{*}{$A D V / S$} & $2.426 * * *$ & $5.036 * * *$ \\
\hline & $(4.785)$ & $(3.413)$ \\
\hline \multirow[t]{2}{*}{ MID } & $0.371 * * *$ & \\
\hline & $(9.942)$ & \\
\hline \multirow[t]{2}{*}{ PNFOR } & $3.509 * * *$ & \\
\hline & $(21.431)$ & \\
\hline \multirow[t]{2}{*}{ STATE_FS/S } & $2.247 * * *$ & \\
\hline & $(10.191)$ & \\
\hline \multirow[t]{2}{*}{$I N V \_M I L L S$} & & 0.001 \\
\hline & & $(0.018)$ \\
\hline \multirow{2}{*}{ Intercept } & $-4.147 * * *$ & $-3.662 * * *$ \\
\hline & $(-22.643)$ & $(-6.888)$ \\
\hline $\mathrm{N}$ & 16,272 & 16,272 \\
\hline Adj-R ${ }^{2}$ & 0.375 & 0.156 \\
\hline \multicolumn{3}{|c|}{ 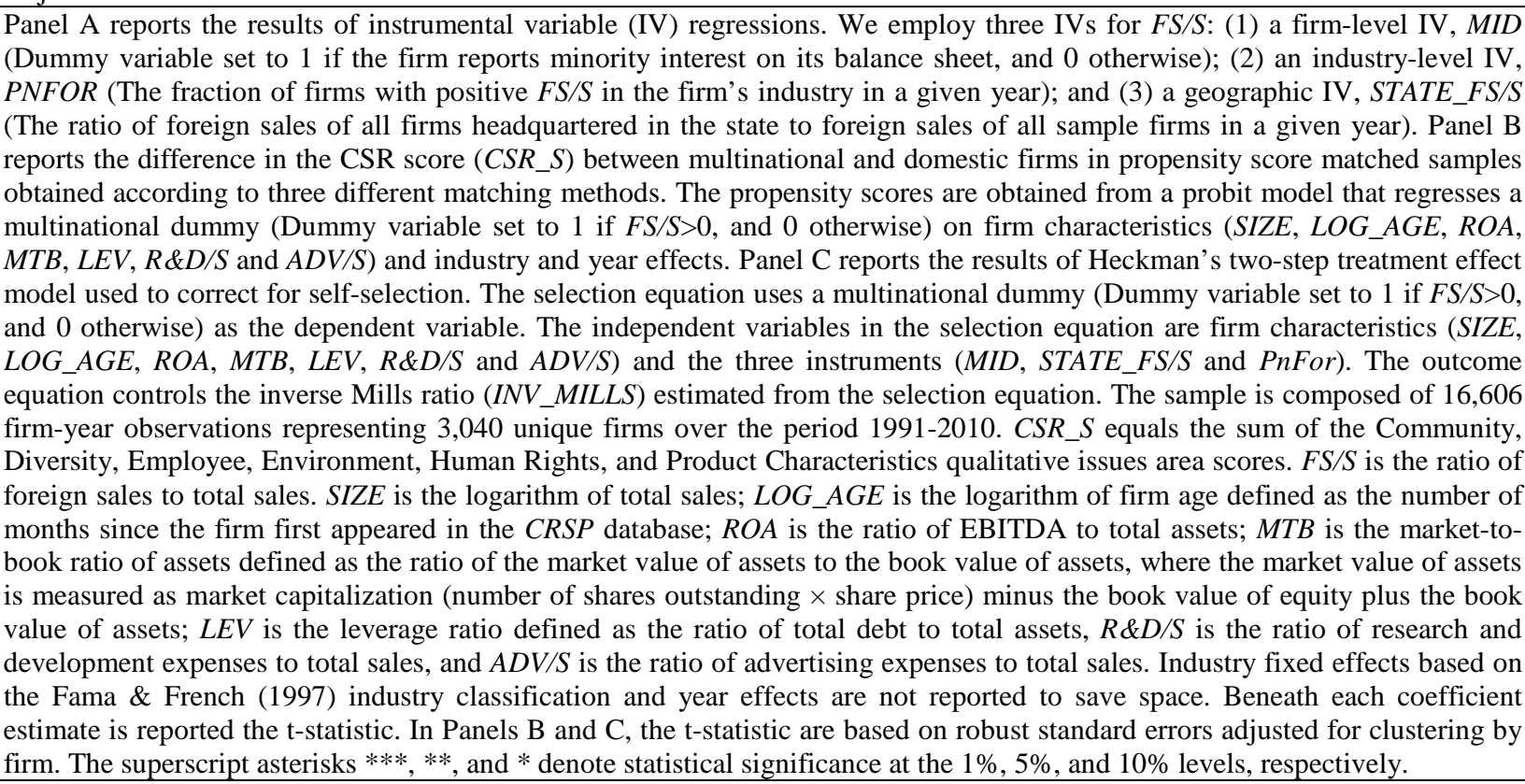 } \\
\hline
\end{tabular}




\section{TABLE 7}

The Relationship between Corporate Social Responsibility and Internationalization: Alternative Estimations and Standard Errors

\begin{tabular}{lcccccc}
\hline & $\begin{array}{c}\text { Firm Fixed } \\
\text { Effects }\end{array}$ & $\begin{array}{c}\text { Firm Random } \\
\text { Effects }\end{array}$ & $\begin{array}{c}\text { Newey- } \\
\text { West }\end{array}$ & $\begin{array}{c}\text { Fama- } \\
\text { McBeth }\end{array}$ & $\begin{array}{c}\text { Prais- } \\
\text { Winsten }\end{array}$ & $\begin{array}{c}\text { Clustering by firm } \\
\text { and Year }\end{array}$ \\
\hline & $(1)$ & $(2)$ & $(3)$ & $(4)$ & $(5)$ & $(6)$ \\
\hline FS/S & $1.075^{* * *}$ & $0.555^{* * *}$ & $0.531^{* * *}$ & $0.750^{* * *}$ & $0.723^{* * *}$ & $0.404^{* * *}$ \\
& $(3.03)$ & $(3.76)$ & $(5.29)$ & $(7.10)$ & $(3.70)$ & $(2.62)$ \\
& -0.046 & $0.159^{* * *}$ & $0.199^{* * *}$ & 0.061 & $0.449^{* * *}$ & $0.246^{* * *}$ \\
LOG__AGE & $(-0.59)$ & $(5.15)$ & $(8.34)$ & $(1.16)$ & $(10.70)$ & $(3.14)$ \\
& -0.095 & $0.074^{* * *}$ & $0.082^{* * *}$ & -0.058 & $-0.131^{*}$ & $0.127^{* * *}$ \\
ROA & $(-1.41)$ & $(2.70)$ & $(3.40)$ & $(-1.01)$ & $(-1.93)$ & $(3.39)$ \\
& $0.372^{* *}$ & $0.226^{* *}$ & $0.567^{* * *}$ & $2.209^{* * *}$ & $-0.272^{* *}$ & $0.601^{* *}$ \\
& $(2.06)$ & $(2.06)$ & $(2.62)$ & $(4.35)$ & $(-2.17)$ & $(2.05)$ \\
MTB & -0.029 & 0.030 & $0.146^{* * *}$ & $0.093^{* * *}$ & 0.011 & $0.171^{* * *}$ \\
& $(-1.13)$ & $(1.48)$ & $(7.40)$ & $(3.30)$ & $(0.64)$ & $(6.17)$ \\
LEV & 0.062 & -0.152 & $-0.439^{* * *}$ & -0.001 & -0.097 & $-0.411^{* *}$ \\
& $(0.27)$ & $(-0.95)$ & $(-3.48)$ & $(-0.00)$ & $(-0.66)$ & $(-2.21)$ \\
$R \& D / S$ & 0.123 & $0.448^{* * *}$ & $0.717^{* * *}$ & $1.593^{*}$ & $0.559 * * *$ & $0.752^{* * *}$ \\
& $(0.62)$ & $(3.72)$ & $(5.34)$ & $(2.07)$ & $(3.22)$ & $(3.21)$ \\
ADV/S & 0.303 & $2.310^{* *}$ & $5.145^{* * *}$ & $4.866^{* * *}$ & 1.354 & $5.254^{* * *}$ \\
& $(0.16)$ & $(2.19)$ & $(5.56)$ & $(5.22)$ & $(1.10)$ & $(3.76)$ \\
Intercept & 0.515 & $-2.889^{* * *}$ & $-3.754^{* * *}$ & $-1.894^{* * *}$ & $-5.438^{* * *}$ & $-4.039^{* * *}$ \\
& $(0.79)$ & $(-7.65)$ & $(-11.69)$ & $(-3.17)$ & $(-5.54)$ & $(-5.66)$ \\
$\mathrm{N}$ & 16,606 & 16,606 & 16,606 & 16,606 & 12,431 & 16,606 \\
Adj-R ${ }^{2} / \mathrm{R}^{2}$ & 0.015 & 0.13 & 0.015 & 0.222 & 0.030 & 0.132 \\
\hline
\end{tabular}

Notes: This table reports results from regressing the CSR score (CSR_S) on internationalization (FS/S) and controls. The sample is composed of 16,606 firm-year observations representing 3,040 unique firms over the period 19912010. CSR_S equals the sum of the Community, Diversity, Employee, Environment, Human Rights, and Product Characteristics qualitative issues area scores. FS/S is the ratio of foreign sales to total sales. SIZE is the logarithm of total sales; $L O G \_A G E$ is the logarithm of firm age defined as the number of months since the firm first appeared in the CRSP database; ROA is the ratio of EBITDA to total assets; MTB is the market-to-book ratio of assets defined as the ratio of the market value of assets to the book value of assets, where the market value of assets is measured as market capitalization (number of shares outstanding $\times$ share price) minus the book value of equity plus the book value of assets; $L E V$ is the leverage ratio defined as the ratio of total debt to total assets, $R \& D / S$ is the ratio of research and development expenses to total sales, and $A D V / S$ is the ratio of advertising expenses to total sales. Industry fixed effects based on the Fama \& French (1997) industry classification and year effects are not reported to save space. Beneath each coefficient estimate is reported the t-statistic. The superscript asterisks ***, **, and * denote statistical significance at the $1 \%, 5 \%$, and $10 \%$ levels, respectively. 


\section{TABLE 8}

The Relationship between Corporate Social Responsibility and Internationalization: Alternative Corporate Social Responsibility Data

\begin{tabular}{|c|c|c|c|}
\hline & Full sample & U.S. firms & Non-U.S. firms \\
\hline & $(1)$ & $(2)$ & (3) \\
\hline \multirow[t]{2}{*}{$F S / S$} & $15.356 * * *$ & $6.951 * *$ & $6.474 * * *$ \\
\hline & (9.22) & $(2.06)$ & (3.45) \\
\hline \multirow[t]{2}{*}{ SIZE } & $10.166 * * *$ & $13.673 * * *$ & $10.110^{* * *}$ \\
\hline & (29.03) & (22.83) & $(25.43)$ \\
\hline \multirow[t]{2}{*}{$R O A$} & 5.345 & 2.000 & -3.941 \\
\hline & (1.07) & $(0.32)$ & $(-0.64)$ \\
\hline \multirow[t]{2}{*}{ MTB } & -0.207 & $1.225 * *$ & $1.484 * *$ \\
\hline & $(-0.39)$ & (2.11) & $(2.14)$ \\
\hline \multirow[t]{2}{*}{$L E V$} & -0.342 & -2.669 & 3.939 \\
\hline & $(-0.10)$ & $(-0.70)$ & $(0.96)$ \\
\hline \multirow[t]{2}{*}{$R \& D / S$} & $33.700 * * *$ & $78.492 * * *$ & $47.838^{* *}$ \\
\hline & (2.61) & (5.22) & $(2.48)$ \\
\hline \multirow[t]{2}{*}{ Intercept } & $-104.058 * * *$ & $-169.468 * * *$ & $-97.152 * * *$ \\
\hline & $(-12.57)$ & $(-14.20)$ & $(-10.52)$ \\
\hline $\mathrm{N}$ & 11,077 & 4,079 & 6,998 \\
\hline $\operatorname{Adj-R}^{2}$ & 0.347 & 0.464 & 0.354 \\
\hline \multicolumn{4}{|c|}{$\begin{array}{l}\text { Notes: This table reports results from regressing an alternative CSR score on internationalization }(F S / S) \text { and } \\
\text { controls. The full sample is composed of } 11,077 \text { firm-year observations from } 43 \text { countries over the period 1991- } \\
2010 \text {. The alternative CSR score is the average of social performance rating and the environmental performance } \\
\text { rating obtained from the ASSET4 database. FS/S is the ratio of foreign sales to total sales. SIZE is the logarithm of } \\
\text { total sales; } L O G \_A G E \text { is the logarithm of firm age defined as the number of months since the firm first appeared } \\
\text { in the } C R S P \text { database; } R O A \text { is the ratio of EBITDA to total assets; MTB is the market-to-book ratio of assets } \\
\text { defined as the ratio of the market value of assets to the book value of assets, where the market value of assets is } \\
\text { measured as market capitalization (number of shares outstanding } \times \text { share price) minus the book value of equity } \\
\text { plus the book value of assets; } L E V \text { is the leverage ratio defined as the ratio of total debt to total assets, } R \& D / S \text { is } \\
\text { the ratio of research and development expenses to total sales, and } A D V / S \text { is the ratio of advertising expenses to } \\
\text { total sales. Industry fixed effects based on the Fama \& French (1997) industry classification and year effects are } \\
\text { not reported to save space. Beneath each coefficient estimate is reported the t-statistic based on robust standard } \\
\text { errors adjusted for clustering by firm. The superscript asterisks } * * *, * * \text {, and * denote statistical significance at the } \\
1 \%, 5 \% \text {, and } 10 \% \text { levels, respectively. }\end{array}$} \\
\hline
\end{tabular}




\section{TABLE 9}

The Relationship between Corporate Social Responsibility Components and Internationalization

\begin{tabular}{|c|c|c|c|c|c|c|c|c|c|}
\hline & CSR_STR_S & CSR_CON_S & CSR_COM_S & $C S R \_D I V \_S$ & CSR_EMP_S & CSR_ENV_S & CSR_HUM_S & CSR_PRO_S & PFC_CSR_S \\
\hline & (1) & (2) & (3) & (4) & (5) & (6) & (7) & (8) & (9) \\
\hline \multirow[t]{2}{*}{$F S / S$} & $0.599 * * *$ & 0.067 & $0.090 * * *$ & $0.318 * * *$ & -0.025 & $0.202 * * *$ & $-0.052 * * *$ & 0.010 & $0.260 * * *$ \\
\hline & $(4.65)$ & $(0.72)$ & (2.63) & $(4.06)$ & $(-0.42)$ & $(4.25)$ & $(-3.32)$ & $(0.24)$ & $(4.02)$ \\
\hline \multirow[t]{2}{*}{ SIZE } & $0.662 * * *$ & $0.463 * * *$ & $0.056 * * *$ & $0.320 * * *$ & 0.019 & $-0.039 * * *$ & $-0.034 * * *$ & $-0.118 * * *$ & $0.124^{* * *}$ \\
\hline & (16.66) & (18.14) & $(5.85)$ & (16.52) & (1.41) & $(-3.06)$ & $(-8.48)$ & $(-12.08)$ & (6.67) \\
\hline \multirow[t]{2}{*}{$L O G \_A G E$} & $0.163 * * *$ & $0.082 * * *$ & 0.011 & $0.093 * * *$ & $0.022^{*}$ & $-0.022 *$ & $-0.013 * * *$ & -0.009 & $0.036 * *$ \\
\hline & (5.25) & (3.36) & (1.41) & $(4.88)$ & $(1.72)$ & $(-1.83)$ & $(-3.83)$ & $(-0.91)$ & $(2.28)$ \\
\hline \multirow[t]{2}{*}{$R O A$} & $-0.232 *$ & $-0.799 * * *$ & 0.001 & -0.065 & $0.290 * *$ & $0.157 * *$ & $0.025^{*}$ & $0.152 * * *$ & $0.189 * *$ \\
\hline & $(-1.79)$ & $(-2.78)$ & $(0.03)$ & $(-0.88)$ & (2.09) & $(2.51)$ & (1.94) & (3.15) & (2.14) \\
\hline \multirow[t]{2}{*}{ MTB } & $0.145^{* * *}$ & -0.000 & $0.022 * * *$ & $0.050 * * *$ & $0.047 * * *$ & $0.016 * *$ & -0.002 & $0.013^{*}$ & $0.063 * * *$ \\
\hline & $(6.27)$ & $(-0.01)$ & (3.31) & (3.38) & $(4.38)$ & $(2.48)$ & $(-0.87)$ & (1.67) & (5.51) \\
\hline \multirow[t]{2}{*}{$L E V$} & $-0.563 * * *$ & -0.124 & -0.032 & $-0.328 * * *$ & $-0.146^{* *}$ & 0.025 & 0.027 & 0.012 & $-0.176^{* *}$ \\
\hline & $(-3.49)$ & $(-1.01)$ & $(-0.84)$ & $(-3.21)$ & $(-2.03)$ & $(0.45)$ & (1.43) & $(0.24)$ & $(-2.21)$ \\
\hline \multirow[t]{2}{*}{$R \& D / S$} & $1.348 * * *$ & $0.631 * * *$ & $0.105 * * *$ & $0.640 * * *$ & 0.093 & -0.038 & $-0.084 * * *$ & 0.002 & $0.313^{* * *}$ \\
\hline & $(8.61)$ & $(4.32)$ & (2.96) & (6.64) & (1.14) & $(-0.79)$ & $(-6.20)$ & $(0.04)$ & (4.06) \\
\hline \multirow[t]{2}{*}{$A D V / S$} & $4.734 * * *$ & -0.411 & $1.097 * * *$ & $3.936 * * *$ & 0.756 & 0.564 & $-0.227^{*}$ & $-0.817^{*}$ & $2.680 * * *$ \\
\hline & (3.73) & $(-0.52)$ & $(2.58)$ & (5.13) & (1.37) & (1.50) & $(-1.80)$ & $(-1.78)$ & (4.10) \\
\hline \multirow[t]{2}{*}{ Intercept } & $-4.344 * * *$ & -0.590 & $-0.582 * * *$ & $-3.856 * * *$ & $-0.471 * * *$ & 0.253 & $0.259 * * *$ & $0.590 * * *$ & $-1.750 * * *$ \\
\hline & $(-9.47)$ & $(-1.58)$ & $(-4.50)$ & $(-16.68)$ & $(-2.93)$ & (1.47) & $(4.77)$ & (5.33) & $(-7.07)$ \\
\hline $\mathrm{N}$ & 16,606 & 16,606 & 16,606 & 16,606 & 16,606 & 16,606 & 15,299 & 16,606 & 16,606 \\
\hline Adj-R ${ }^{2}$ & 0.318 & 0.317 & 0.133 & 0.296 & 0.099 & 0.149 & 0.116 & 0.179 & 0.181 \\
\hline
\end{tabular}

Notes: This table reports results from regressing CSR components on internationalization (FS/S) and controls. The sample is composed of 16,606 firm-year observations representing 3,040 unique firms over the period 1991-2010. CSR_COM_S equals the number of strengths minus the number of concerns in the Community qualitative issue area; $C S R \_D I V \_S$ equals the number of strengths minus the number of concerns in the Diversity qualitative issue area; $C S R \_E M P \_S$ equals to the number of strengths minus the number of concerns in the Employee Relations qualitative issue area; CSR_ENV_S equals the number of strengths minus the number of concerns in the Environment qualitative issue area; CSR_HUM_S equals the number of strengths minus the number of concerns in the Human Rights qualitative issue area; $C S R \_P R O \_S$ equals the number of strengths minus the number of concerns in the Product qualitative issue area; $P F C \_C S R \_S$ is the principal factor component of $C S R \_C O M \_S, C S R \_D I V \_S, C S R \_E M P \_S$, $C S R \_E N V \_S$

CSR_HUM_S and CSR_PRO_S; and CSR_STR_S (CSR_CON_S) equals the total number of strengths (concerns) of the Community, Diversity, Employee, Environment, Human Rights, and Product Characteristics qualitative issue areas. FS/S is the ratio of foreign sales to total sales. SIZE is the logarithm of total sales; $L O G$ AGE is the logarithm of firm age defined as the number of months since the firm first appeared in the CRSP database; ROA is the ratio of EBITDA to total assets; MTB is the market-to-book ratio of assets defined as the ratio of the market value of assets to the book value of assets, where the market value of assets is measured as market capitalization (number of shares outstanding $\times$ share price) minus the book value of equity plus the book value of assets; $L E V$ is the leverage ratio defined as the ratio of total debt to total assets, $R \& D / S$ is the ratio of research and development expenses to total sales, and $A D V / S$ is the ratio of advertising expenses to total sales. Industry fixed effects based on the Fama \& French (1997) industry classification and year effects are not reported to save space. Beneath each coefficient estimate is reported the t-statistic based on robust standard errors adjusted for clustering by firm. The superscript asterisks $* * *, * *$, and $*$ denote statistical significance at the $1 \%, 5 \%$, and $10 \%$ levels, respectively. 


\section{TABLE 10}

The Relationship between Corporate Social Responsibility and Internationalization: Does the Institutional Environments of Countries in which the Firm Discloses Subsidiaries Play a Role?

\begin{tabular}{|c|c|c|c|c|c|c|c|}
\hline & POLIT_RISK & GOVT_STAB & INV_PROFILE & CORRUPT & LAW_ORDER & DEMOC & BUREAUCR \\
\hline & $(1)$ & $(2)$ & (3) & (4) & (5) & (6) & (7) \\
\hline$F S / S$ & $\begin{array}{c}0.565^{* * *} \\
(2.81)\end{array}$ & $\begin{array}{c}0.517 * * \\
(2.57)\end{array}$ & $\begin{array}{c}0.579 * * * \\
(2.87)\end{array}$ & $\begin{array}{c}0.606 * * * \\
(2.99)\end{array}$ & $\begin{array}{c}0.583^{* * *} \\
(2.89)\end{array}$ & $\begin{array}{c}0.608 * * * \\
(2.99)\end{array}$ & $\begin{array}{c}0.611^{* * *} \\
(3.02)\end{array}$ \\
\hline SIZE & $\begin{array}{c}0.270 * * * \\
(4.53)\end{array}$ & $\begin{array}{c}0.269 * * * \\
(4.51)\end{array}$ & $\begin{array}{c}0.271 * * * \\
(4.56)\end{array}$ & $\begin{array}{c}0.268 * * * \\
(4.49)\end{array}$ & $\begin{array}{c}0.268 * * * \\
(4.49)\end{array}$ & $\begin{array}{c}0.266^{* * * *} \\
(4.47)\end{array}$ & $\begin{array}{c}0.270 * * * \\
(4.53)\end{array}$ \\
\hline$L O G \_A G E$ & $\begin{array}{l}0.103^{*} \\
(1.85)\end{array}$ & $\begin{array}{l}0.101^{*} \\
(1.81)\end{array}$ & $\begin{array}{l}0.103^{*} \\
(1.84)\end{array}$ & $\begin{array}{l}0.100^{*} \\
(1.79)\end{array}$ & $\begin{array}{l}0.101^{*} \\
(1.81)\end{array}$ & $\begin{array}{l}0.102^{*} \\
(1.82)\end{array}$ & $\begin{array}{l}0.104^{*} \\
(1.85)\end{array}$ \\
\hline$R O A$ & $\begin{array}{l}0.446^{*} \\
(1.85)\end{array}$ & $\begin{array}{l}0.433^{*} \\
(1.74)\end{array}$ & $\begin{array}{l}0.451^{*} \\
(1.87)\end{array}$ & $\begin{array}{l}0.458^{*} \\
(1.82)\end{array}$ & $\begin{array}{l}0.454^{*} \\
(1.84)\end{array}$ & $\begin{array}{l}0.455^{*} \\
(1.85)\end{array}$ & $\begin{array}{l}0.454^{*} \\
(1.87)\end{array}$ \\
\hline MTB & $\begin{array}{c}0.159 * * * \\
(4.45)\end{array}$ & $\begin{array}{c}0.160 * * * \\
(4.48)\end{array}$ & $\begin{array}{c}0.160^{* * * *} \\
(4.46)\end{array}$ & $\begin{array}{c}0.161^{* * * *} \\
(4.50)\end{array}$ & $\begin{array}{c}0.160 * * * \\
(4.47)\end{array}$ & $\begin{array}{c}0.161^{* * *} \\
(4.47)\end{array}$ & $\begin{array}{c}0.160 * * * \\
(4.46)\end{array}$ \\
\hline$L E V$ & $\begin{array}{l}-0.292 \\
(-1.00)\end{array}$ & $\begin{array}{l}-0.277 \\
(-0.95)\end{array}$ & $\begin{array}{l}-0.293 \\
(-1.00)\end{array}$ & $\begin{array}{l}-0.324 \\
(-1.10)\end{array}$ & $\begin{array}{l}-0.309 \\
(-1.05)\end{array}$ & $\begin{array}{l}-0.332 \\
(-1.13)\end{array}$ & $\begin{array}{l}-0.313 \\
(-1.07)\end{array}$ \\
\hline$R \& D / S$ & $\begin{array}{c}1.629 * * * \\
(3.63)\end{array}$ & $\begin{array}{c}1.629 * * * \\
(3.65)\end{array}$ & $\begin{array}{c}1.624 * * * \\
(3.61)\end{array}$ & $\begin{array}{c}1.612^{* * *} \\
(3.57)\end{array}$ & $\begin{array}{c}1.597 * * * \\
(3.54)\end{array}$ & $\begin{array}{c}1.646^{* * * *} \\
(3.63)\end{array}$ & $\begin{array}{c}1.586^{* * *} \\
(3.52)\end{array}$ \\
\hline$A D V / S$ & $\begin{array}{c}4.880^{* *} \\
(2.55)\end{array}$ & $\begin{array}{c}4.959 * * * \\
(2.59)\end{array}$ & $\begin{array}{c}4.857 * * \\
(2.53)\end{array}$ & $\begin{array}{c}4.835 * * \\
(2.52)\end{array}$ & $\begin{array}{c}4.735 * * \\
(2.46)\end{array}$ & $\begin{array}{c}4.910^{* *} \\
(2.55)\end{array}$ & $\begin{array}{c}4.848^{* *} \\
(2.52)\end{array}$ \\
\hline$V A R$ & $\begin{array}{c}0.013^{* * *} \\
(3.93)\end{array}$ & $\begin{array}{c}0.114^{* * *} \\
(4.19)\end{array}$ & $\begin{array}{c}0.086^{* * *} \\
(3.77)\end{array}$ & $\begin{array}{c}0.120^{* *} \\
(2.36)\end{array}$ & $\begin{array}{c}0.122^{* * *} \\
(2.74)\end{array}$ & $\begin{array}{c}0.111^{* * *} \\
(2.66)\end{array}$ & $\begin{array}{c}0.214^{* * *} \\
(3.20)\end{array}$ \\
\hline Intercept & $\begin{array}{c}-5.836 * * * \\
(-6.19)\end{array}$ & $\begin{array}{c}-5.680 * * * \\
(-6.04)\end{array}$ & $\begin{array}{c}-5.747 * * * \\
(-6.06)\end{array}$ & $\begin{array}{c}-5.398 * * * \\
(-5.71)\end{array}$ & $\begin{array}{c}-5.473 * * * \\
(-5.81)\end{array}$ & $\begin{array}{c}-5.488 * * * \\
(-5.74)\end{array}$ & $\begin{array}{c}-5.628 * * * \\
(-6.02)\end{array}$ \\
\hline $\begin{array}{l}\mathrm{N} \\
\text { Adj-R }^{2}\end{array}$ & $\begin{array}{l}7,159 \\
0.202\end{array}$ & $\begin{array}{l}7,159 \\
0.201\end{array}$ & $\begin{array}{l}7,159 \\
0.201\end{array}$ & $\begin{array}{l}7,159 \\
0.199\end{array}$ & $\begin{array}{l}7,159 \\
0.199\end{array}$ & $\begin{array}{l}7,159 \\
0.199\end{array}$ & $\begin{array}{l}7,159 \\
0.200\end{array}$ \\
\hline
\end{tabular}

Notes: This table reports results from regressing the CSR score (CSR_S) on internationalization (FS/S) and controls. The sample is composed of 16,606 firm-year observations representing 3,040 unique firms over the period 1991-2010. CSR_S equals the sum of the Community, Diversity, Employee, Environment, Human Rights, and Product Characteristics qualitative issues area scores. FS/S is the ratio of foreign sales to total sales. SIZE is the logarithm of total sales; $L O G \_A G E$ is the logarithm of firm age defined as the number of months since the firm first appeared in the CRSP database; $R O A$ is the ratio of EBITDA to total assets; MTB is the market-to-book ratio of assets defined as the ratio of the market value of assets to the book value of assets, where the market value of assets is measured as market capitalization (number of shares outstanding $\times$ share price) minus the book value of equity plus the book value of assets; $L E V$ is the leverage ratio defined as the ratio of total debt to total assets, $R \& D / S$ is the ratio of research and development expenses to total sales, and $A D V / S$ is the ratio of advertising expenses to total sales. POLIT_RISK is the weighted average political risk rating of countries in which the firm discloses subsidiaries in Exhibit 21 of Form 10-K; GOVT_STAB is the weighted average government stability rating of countries in which the firm discloses subsidiaries in Exhibit 21 of Form 10-K; INV_PROFILE is the weighted average government investment profile of countries in which the firm discloses subsidiaries in Exhibit 21 of Form 10-K; CORRUPT is the weighted average corruption control rating of countries in which the firm discloses subsidiaries in Exhibit 21 of Form 10-K; LAW_ORDER is the weighted average law and order rating of countries in which the firm discloses subsidiaries in Exhibit 21 of Form 10-K; DEMOC is the weighted average democratic accountability rating of countries in which the firm discloses subsidiaries in Exhibit 21 of Form 10-K; BUREAUCR is the weighted average quality of bureaucracy rating of countries in which the firm discloses subsidiaries in Exhibit 21 of Form 10-K. Weights are equal to the number of subsidiaries in each country. All Institutional variables are obtained from the International Country Risk Guide. Data on subsidiaries come from Dyreng \& Lindsey (2009). Industry fixed effects based on the Fama \& French (1997) industry classification and year effects are not reported to save space. Beneath each coefficient estimate is reported the t-statistic based on robust standard errors adjusted for clustering by firm. The superscript asterisks ***, **, and * denote statistical significance at the $1 \%, 5 \%$, and $10 \%$ levels, respectively. 
TABLE 11

The Relationship between Corporate Social Responsibility and Internationalization: Conditioning on Firm Characteristics

\begin{tabular}{|c|c|c|c|c|c|c|c|c|c|c|c|c|c|c|}
\hline & \multicolumn{2}{|c|}{ SIZE } & \multicolumn{2}{|c|}{ LOG_AGE } & \multicolumn{2}{|c|}{$R O A$} & \multicolumn{2}{|c|}{ MTB } & \multicolumn{2}{|c|}{$L E V$} & \multicolumn{2}{|c|}{$R \& D / S$} & \multicolumn{2}{|c|}{$\overline{A D V / S}$} \\
\hline & Low & High & Low & High & Low & High & Low & High & Low & High & Low & High & Low & High \\
\hline & (1) & (2) & (3) & (4) & (5) & (6) & (7) & (8) & (9) & (10) & (11) & $(12)$ & (13) & (14) \\
\hline$F S / S$ & $\begin{array}{l}-0.003 \\
(-0.03)\end{array}$ & $\begin{array}{c}0.667 * * \\
(2.33)\end{array}$ & $\begin{array}{l}0.231 \\
(1.50)\end{array}$ & $\begin{array}{c}0.849 * * * \\
(3.28)\end{array}$ & $\begin{array}{l}0.213 \\
(1.21)\end{array}$ & $\begin{array}{c}0.701^{* * *} \\
(3.41)\end{array}$ & $\begin{array}{l}0.236 \\
(1.23)\end{array}$ & $\begin{array}{c}0.534^{* * *} \\
(2.89)\end{array}$ & $\begin{array}{c}0.577 * * * \\
(3.27)\end{array}$ & $\begin{array}{c}0.485^{* *} \\
(2.04)\end{array}$ & $\begin{array}{l}0.221 \\
(1.02)\end{array}$ & $\begin{array}{c}0.414^{* *} \\
(2.08)\end{array}$ & $\begin{array}{l}0.179 \\
(1.12)\end{array}$ & $\begin{array}{c}0.737 * * * \\
(2.58)\end{array}$ \\
\hline SIZE & $\begin{array}{l}0.048 \\
(1.27)\end{array}$ & $\begin{array}{c}0.381^{* * *} \\
(4.72)\end{array}$ & $\begin{array}{c}0.094^{* *} \\
(2.24)\end{array}$ & $\begin{array}{c}0.280 * * * \\
(4.88)\end{array}$ & $\begin{array}{l}0.069 \\
(1.50)\end{array}$ & $\begin{array}{c}0.319 * * * \\
(6.01)\end{array}$ & $\begin{array}{l}-0.011 \\
(-0.23)\end{array}$ & $\begin{array}{c}0.410^{* * *} \\
(8.16)\end{array}$ & $\begin{array}{c}0.290^{* * *} \\
(5.32)\end{array}$ & $\begin{array}{c}0.092 \\
(1.62)\end{array}$ & $\begin{array}{l}-0.037 \\
(-0.93)\end{array}$ & $\begin{array}{c}0.441 * * * \\
(7.34)\end{array}$ & $\begin{array}{l}0.033 \\
(0.79)\end{array}$ & $\begin{array}{c}0.430 * * * \\
(6.38)\end{array}$ \\
\hline$L O G \_A G E$ & $\begin{array}{l}-0.024 \\
(-0.78)\end{array}$ & $\begin{array}{c}0.122^{* *} \\
(1.98)\end{array}$ & $\begin{array}{c}0.088^{* *} \\
(2.42)\end{array}$ & $\begin{array}{l}-0.083 \\
(-0.52)\end{array}$ & $\begin{array}{l}0.031 \\
(0.67)\end{array}$ & $\begin{array}{c}0.096^{* *} \\
(2.06)\end{array}$ & $\begin{array}{l}0.007 \\
(0.15)\end{array}$ & $\begin{array}{c}0.094 * * \\
(2.02)\end{array}$ & $\begin{array}{l}0.051 \\
(1.18)\end{array}$ & $\begin{array}{c}0.090^{*} \\
(1.73)\end{array}$ & $\begin{array}{l}0.001 \\
(0.02)\end{array}$ & $\begin{array}{c}0.139 * * \\
(2.28)\end{array}$ & $\begin{array}{l}0.009 \\
(0.19)\end{array}$ & $\begin{array}{c}0.162 * * * \\
(2.96)\end{array}$ \\
\hline$R O A$ & $\begin{array}{c}0.342 * * \\
(2.10)\end{array}$ & $\begin{array}{c}1.563^{* * *} \\
(2.03)\end{array}$ & $\begin{array}{l}0.239 * \\
(1.77)\end{array}$ & $\begin{array}{c}1.921^{* * * *} \\
(4.38)\end{array}$ & $\begin{array}{l}0.235^{*} \\
(1.66)\end{array}$ & $\begin{array}{c}1.632^{* * *} \\
(2.46)\end{array}$ & $\begin{array}{l}0.422 \\
(1.00)\end{array}$ & $\begin{array}{l}0.141 \\
(1.11)\end{array}$ & $\begin{array}{l}0.321^{*} \\
(1.80)\end{array}$ & $\begin{array}{c}1.121^{* * *} \\
(3.74)\end{array}$ & $\begin{array}{l}0.161 \\
(0.46)\end{array}$ & $\begin{array}{l}0.418^{*} \\
(1.73)\end{array}$ & $\begin{array}{c}0.415^{* *} \\
(1.99)\end{array}$ & $\begin{array}{c}0.662^{*} \\
(1.67)\end{array}$ \\
\hline MTB & $\begin{array}{c}0.048^{* *} \\
(2.03)\end{array}$ & $\begin{array}{c}0.184^{* * *} \\
(2.89)\end{array}$ & $\begin{array}{c}0.088^{* * * *} \\
(3.39)\end{array}$ & $\begin{array}{c}0.224 * * * \\
(4.43)\end{array}$ & $\begin{array}{l}0.008 \\
(0.21)\end{array}$ & $\begin{array}{c}0.110^{* * *} \\
(2.78)\end{array}$ & $\begin{array}{c}0.444 * * * \\
(2.66)\end{array}$ & $\begin{array}{c}0.109 * * * \\
(3.76)\end{array}$ & $\begin{array}{c}0.095 * * * \\
(3.37)\end{array}$ & $\begin{array}{c}0.294^{* * *} \\
(6.29)\end{array}$ & $\begin{array}{c}0.174 * * * \\
(4.22)\end{array}$ & $\begin{array}{c}0.113^{* * *} \\
(3.68)\end{array}$ & $\begin{array}{c}0.095 * * * \\
(3.08)\end{array}$ & $\begin{array}{c}0.166^{* * *} \\
(4.11)\end{array}$ \\
\hline$L E V$ & $\begin{array}{c}-0.443 * * * \\
(-2.79)\end{array}$ & $\begin{array}{l}-0.361 \\
(-1.00)\end{array}$ & $\begin{array}{c}-0.526 * * * \\
(-3.05)\end{array}$ & $\begin{array}{l}-0.227 \\
(-0.63)\end{array}$ & $\begin{array}{l}-0.294 \\
(-1.10)\end{array}$ & $\begin{array}{c}-0.391 * \\
(-1.68)\end{array}$ & $\begin{array}{l}-0.525^{*} \\
(-1.84)\end{array}$ & $\begin{array}{l}-0.263 \\
(-1.21)\end{array}$ & $\begin{array}{l}-0.249 \\
(-0.35)\end{array}$ & $\begin{array}{c}-1.142 * * * \\
(-3.76)\end{array}$ & $\begin{array}{c}-0.513^{* *} \\
(-2.35)\end{array}$ & $\begin{array}{l}-0.480 \\
(-1.55)\end{array}$ & $\begin{array}{l}-0.181 \\
(-0.73)\end{array}$ & $\begin{array}{c}-0.959 * * * \\
(-3.46)\end{array}$ \\
\hline$R \& D / S$ & $\begin{array}{l}0.240^{*} \\
(1.72)\end{array}$ & $\begin{array}{c}8.544 * * * \\
(5.13)\end{array}$ & $\begin{array}{l}0.252 \\
(1.60)\end{array}$ & $\begin{array}{c}1.856 * * * \\
(4.51)\end{array}$ & $\begin{array}{l}0.186 \\
(1.14)\end{array}$ & $\begin{array}{c}5.545^{* * *} \\
(5.16)\end{array}$ & $\begin{array}{l}0.361 \\
(1.18)\end{array}$ & $\begin{array}{c}1.051^{* * *} \\
(5.23)\end{array}$ & $\begin{array}{c}0.959 * * * \\
(4.67)\end{array}$ & $\begin{array}{l}0.429 \\
(1.41)\end{array}$ & $\begin{array}{c}-175.711 * \\
(-1.88)\end{array}$ & $\begin{array}{c}1.241 * * * \\
(5.67)\end{array}$ & $\begin{array}{l}0.113 \\
(0.58)\end{array}$ & $\begin{array}{c}1.541^{* * *} \\
(3.81)\end{array}$ \\
\hline$A D V / S$ & $\begin{array}{l}0.779 \\
(0.62)\end{array}$ & $\begin{array}{c}8.354 * * * \\
(3.36)\end{array}$ & $\begin{array}{c}4.349 * * * \\
(3.23)\end{array}$ & $\begin{array}{c}8.131^{* * * *} \\
(2.81)\end{array}$ & $\begin{array}{c}6.175^{* * * *} \\
(3.67)\end{array}$ & $\begin{array}{l}3.209 * \\
(1.86)\end{array}$ & $\begin{array}{c}5.538 * * * \\
(2.73)\end{array}$ & $\begin{array}{c}2.589 * \\
(1.67)\end{array}$ & $\begin{array}{c}4.530 * * * \\
(2.58)\end{array}$ & $\begin{array}{c}5.300^{* *} \\
(2.50)\end{array}$ & $\begin{array}{c}5.167 * * \\
(2.47)\end{array}$ & $\begin{array}{l}3.492 * \\
(1.86)\end{array}$ & & $\begin{array}{l}2.868 * \\
(1.81)\end{array}$ \\
\hline Intercept & $\begin{array}{c}-1.980 * * * \\
(-4.30)\end{array}$ & $\begin{array}{c}-5.871 * * * \\
(-6.44)\end{array}$ & $\begin{array}{c}-3.191 * * * \\
(-5.33)\end{array}$ & $\begin{array}{c}-3.711^{* * * *} \\
(-3.56)\end{array}$ & $\begin{array}{c}-2.344 * * * \\
(-4.12)\end{array}$ & $\begin{array}{c}-4.860 * * * \\
(-6.66)\end{array}$ & $\begin{array}{c}-2.188 * * * \\
(-3.65)\end{array}$ & $\begin{array}{c}-4.795^{* * *} \\
(-6.46)\end{array}$ & $\begin{array}{c}-3.733^{* * *} \\
(-4.16)\end{array}$ & $\begin{array}{c}-2.921 * * * \\
(-4.40)\end{array}$ & $\begin{array}{c}-2.177 * * * \\
(-4.58)\end{array}$ & $\begin{array}{c}-4.621^{* * *} \\
(-5.34)\end{array}$ & $\begin{array}{c}-2.191 * * * \\
(-3.66)\end{array}$ & $\begin{array}{c}-5.233 * * * \\
(-8.35)\end{array}$ \\
\hline $\mathrm{N}$ & 8,302 & 8,304 & 8,333 & 8,273 & 8,304 & 8,302 & 8,304 & 8,302 & 8,306 & 8,300 & 8,359 & 8,247 & 9,861 & 6,745 \\
\hline Adj-R ${ }^{2}$ & 0.221 & 0.238 & 0.186 & 0.198 & 0.118 & 0.206 & 0.120 & 0.210 & 0.175 & 0.163 & 0.158 & 0.214 & 0.125 & 0.235 \\
\hline
\end{tabular}

Notes: This table reports results from regressing the CSR score (CSR_S) on internationalization (FS/S) and controls across subsamples of firms sorted by firm characteristics. The Low (High) subsample is comprised of firms with below (above) median characteristic in a given year. The sample is composed of 16,606 firm-year observations representing 3,040 unique firms over the period 1991-2010. CSR_S equals the sum of the Community, Diversity, Employee, Environment, Human Rights, and Product Characteristics qualitative issues area scores. FS/S is the ratio of foreign sales to total sales. SIZE is the logarithm of total sales; LOG_AGE is the logarithm of firm age defined as the number of months since the firm first appeared in the CRSP database; ROA is the ratio of EBITDA to total assets; MTB is the market-to-book ratio of assets defined as the ratio of the market value of assets to the book value of assets, where the market value of assets is measured as market capitalization (number of shares outstanding $\times$ share price) minus the book value of equity plus the book value of assets; $L E V$ is the leverage ratio defined as the ratio of total debt to total assets, $R \& D / S$ is the ratio of research and development expenses to total sales, and $A D V / S$ is the ratio of advertising expenses to total sales. Industry fixed effects based on the Fama \& French (1997) industry classification and year effects are not reported to save space. Beneath each coefficient estimate is reported the t-statistic based on robust standard errors adjusted for clustering by firm. The superscript asterisks $* * *, * *$, and $*$ denote statistical significance at the $1 \%, 5 \%$, and $10 \%$ levels, respectively. 